\title{
Dimethylphosphinate bridged Binuclear Rh(I) Catalysts for the Alkoxycarbonylation of Aromatic $\mathrm{C}-\mathrm{H}$ bonds
}

\author{
Amaia Iturmendi, Pablo J. Sanz Miguel, Saheed A. Popoola, Abdulaziz A. Al-Saadi, Manuel Iglesias, * Luis A. Oro*
}

\begin{abstract}
A variety of binuclear rhodium(I) complexes featuring two bridging dimethylphosphinate ligands ((CH3)2PO2-) have been prepared and tested in the alkoxycarbonylation of aromatic $\mathrm{C}-\mathrm{H}$ bonds. Complex [Rh( $\left.\left.\mu-\kappa O, \mathrm{O}^{\prime}-(\mathrm{CH} 3) 2 \mathrm{PO} 2\right)(\mathrm{cod})\right] 2$ has been prepared by reaction of $[R h(\mu-M e O)(c o d)] 2$ with 2 equivalents of dimethylphosphinic acid. Binuclear complexes $\left[R h\left(\mu-\kappa O, O^{\prime}-(C H 3) 2 P O 2\right)(C O) L\right] 2$ $(L=P P h 3, P(O M e) P h 2$ and $P(O P h) 3)$ were obtained by carbonylation of the related mononuclear complexes [Rh(KO$(\mathrm{CH} 3) 2 \mathrm{PO} 2)(\mathrm{COD})(\mathrm{L})]$, which were prepared in situ by reaction of $\left[R h\left(\mu-\kappa O, \mathrm{O}^{\prime}-(\mathrm{CH} 3) 2 \mathrm{PO} 2\right)(\mathrm{cod})\right] 2$ with 2 equivalents of $\mathrm{L}$. Conversely, if $L=I P r$, the reaction of $\left[R h\left(\mu-\kappa O, O^{\prime}-(C H 3) 2 P O 2\right)(C O) L\right] 2$ with carbon monoxide affords the mononuclear complex $[R h(K O-$ (CH3)2PO2)(CO)2IPr]. Subsequent reaction with trimethylamine $N$-oxide gives the corresponding binuclear complex $\left[R h\left(\mu-\kappa O, O^{\prime}-\right.\right.$ (CH3)2PO2)(CO)(IPr)]2 by abstraction of one of the carbonyl ligands. Complexes [Rh( $\left.\left.\mu-k O, \mathrm{O}^{\prime}-(\mathrm{CH} 3) 2 \mathrm{PO} 2\right)(\mathrm{cod})\right] 2$ and [Rh(KO$(\mathrm{CH} 3) 2 P O 2)(C O D)(L)](L=I P r, P P h 3, P(O M e) P h 2, P(O P h) 3)$ are active precatalysts in the alkoxycarbonylation of $\mathrm{C}-\mathrm{H}$ bonds, with the ligand system playing a key role on the catalytic activity. The complexes that feature more labile Rh-L bonds give rise to better catalysts, probably due to the more straightforward subtitution of $L$ by a second carbonyl ligand, since a more electrophilic carbonyl carbon atom is more susceptible toward alryl migration. In fact, complexes $\left[R h\left(\mu-\kappa O, O^{\prime}-(C H 3) 2 P O 2\right)(C O) 2\right] 2$ and $[R h(\mu-C l)(C O) 2] 2$, generated in situ from $\left[R h\left(\mu-\kappa O, O^{\prime}-(C H 3) 2 P O 2\right)(C O D)\right] 2$ and $[R h(\mu-C l)(C O D) 2] 2$, respectively, are the most active catalyst of the precatalyst tested in this work.
\end{abstract}

\section{Introduction}

Binuclear rhodium complexes have proved to be excellent catalysts for a range of organic transformations, remarkable examples being the $\mathrm{Rh}_{2}{ }^{11, \|}$ systems reported by Doyle and coworkers, which are efficient catalysts for the synthesis of sixmembered heterocycles by a versatile $[3+3]$-cycloaddition reaction, ${ }^{1}$ and those developed by Stanley et al. for the hydroformylation of 1 -hexene. ${ }^{2}$ In both cases, the active species have been proposed to be binuclear entities that exploit intermetallic cooperation throughout the catalytic cycle to permit the corresponding transformation. ${ }^{3}$ On the other hand, some binuclear rhodium complexes have also been reported to break in situ into unsaturated mononuclear entities that operate as active species in catalysis. These binuclear structures are usually sustained by bridging ligands, such as chlorides, hydrides or alkoxides, but lack metal-metal interactions that further stabilize the complex, which permits the straightforward in situ formation of very reactive unsaturated species under relatively mild reaction conditions. This strategy has been successfully employed for a variety of catalytic transformations, with the functionalization of $\mathrm{C}-\mathrm{H}$ bonds being particularly successful. ${ }^{4}$

Organometallic rhodium carbonyl species have been long known to be active catalysts for carbonylation reactions, for example hydroformylation (the catalyst $\left[\mathrm{Rh}(\mathrm{CO})(\mathrm{H})\left(\mathrm{PPh}_{3}\right)_{3}\right]$ being remarkably important due to its industrial applications), ${ }^{5}$ carbonylation of methanol (the active species in the Monsanto process is the anion $\left.\left[\mathrm{Rh}(\mathrm{CO})_{2} \mathrm{I}_{2}\right]^{-}\right),{ }^{6}$ and the carbonylation of $\mathrm{C}-$ $\mathrm{H}$ bonds by reductive coupling ${ }^{7}$ or by alkoxycarbonylation. ${ }^{8,9}$ The latter is of a remarkable synthetic significance due to the ubiquitous presence of carboxylic acids and esters in natural products and commodity chemicals. ${ }^{10}$ Esters are usually prepared by esterification reactions from carboxylic acids. ${ }^{11}$ However, the functionalization of organic substrates to generate the desired starting material, i.e. the carboxylic acid, is often cumbersome and requires multistep syntheses, especially in the case of non-functionalized hydrocarbons. For example, the oxidation of arene side-chains with $\mathrm{KMnO}_{4}$, primary alcohols with Jone's reagent and the ozonolysis of double bonds are common oxidation methods for the synthesis of carboxylic acids that require the use of stoichiometric amounts of oxidants and the concomitant generation of inorganic salts as by-products. Other synthetic methods entail the use of an organic halide, which can be converted into a nitrile and subsequently hydrolyzed to give the carboxylic acid. The organic halide can also be transformed into an organometallic reagent (Grignard or organolithium compound) and then carboxylated with carbon dioxide. ${ }^{12}$

The alkoxycarbonylation reaction permits the access to esters by direct functionalization of a $\mathrm{C}-\mathrm{H}$ bond, thus rendering a more sustainable and environmentally benign procedure compared to stoichiometric approaches, since they require prior prefunctionalization of the $\mathrm{C}-\mathrm{H}$ bond, followed by the synthesis of the carboxylic acid and, finally, the esterification reaction. ${ }^{9}$

$[\mathrm{Rh}(\mu-\mathrm{Cl})(\operatorname{cod})]_{2}$ (cod $=1,5$-biscyclooctadiene) has proved to be an efficient catalyst for this reaction; ${ }^{8}$ however, this is the only Rh example hitherto reported and, consequently, the influence of the ligand system at the rhodium center has not been evaluated. Palladium(II) complexes have also proved to be active catalysts for the alkoxycarbonylation of aryl $\mathrm{C}-\mathrm{H}$ bonds using carbon monoxide but, in contrast with Rh catalysts, the use of stoichiometric amounts of $\mathrm{Cu}$ or $\mathrm{Ag}$ reagents is always required. ${ }^{9}$ For instance, the alkoxycarbonylation of arylpyridines with $\mathrm{Pd}(\mathrm{OAc})_{2}$ requires the use a $10 \mathrm{~mol} \%$ catalyst 
loading, 1 equivalent of $\mathrm{CuBr}_{2}$ and 1 equivalent of $\mathrm{NaOAc}$, as well as the use of a $\mathrm{CO} / \mathrm{O}_{2}(4: 1)$ atmosphere. ${ }^{13}$ In the case of indole and thiophene derivatives the use of a $5 \mathrm{~mol} \%$ of $\mathrm{PdCl}_{2}\left(\mathrm{PPh}_{3}\right)_{2}, 10 \mathrm{~mol} \% \mathrm{PPh}_{3}, 2$ equivalents of $\mathrm{Cu}(\mathrm{OAc})_{2}$ and 1 atm of $\mathrm{CO}$ is required. ${ }^{14}$

Rhodium complexes featuring phosphine oxides as ligands are excellent catalysts for the carbonylation of methanol. In this regard, Wegman et al. demonstrated that the complex cis$\mathrm{Rh}\left[\left(\mathrm{Ph}_{2} \mathrm{P}\left(\mathrm{CH}_{2}\right)_{2} \mathrm{P}(\mathrm{O}) \mathrm{Ph}_{2}\right)(\mathrm{CO}) \mathrm{Cl}\right],{ }^{15}$ which contains a ditopic hemilable ligand, is extremely active under very mild reaction conditions. Related complexes, such as cis$\left[\mathrm{Rhl}(\mathrm{CO})\left(\mathrm{Ph}_{2} \mathrm{PCH}_{2} \mathrm{P}(\mathrm{S}) \mathrm{Ph}\right]^{16}\right.$ or Dutta's catalysts $\left[\mathrm{RhCl}(\mathrm{CO})_{2}(\mathrm{~L})\right]$ (where $\mathrm{L}=\mathrm{Ph}_{3} \mathrm{P}=\mathrm{O}, \mathrm{Ph}_{3} \mathrm{P}=\mathrm{S}$ or $\mathrm{Ph}_{3} \mathrm{P}=\mathrm{Se}$ ), have also shown excellent activities, the latter being more active than the Monsanto catalyst $\left(\left[\mathrm{Rh}(\mathrm{CO})_{2} \mathrm{I}_{2}\right]^{-}\right) \cdot{ }^{17}$

In this work we set off to study the coordination chemistry of binuclear $\mathrm{Rh}(\mathrm{I})$-carbonyl complexes sustained by dimethylphosphinate bridges in order to assess the influence of this phosphine oxide ligand in carbonylation reations. ${ }^{18} \mathrm{We}$ envisaged that, upon coordination of the first oxygen atom, the uncoordinated oxygen may weakly bind to a second rhodium center, thus allowing for the facile generation of an unsaturated species. Wegman's complex, for example, reacts readily with $\mathrm{CO}$ by displacing the phosphine oxide to give the carbonyl complex. The coordination of a $\mathrm{CO}$ molecule and the migratory insertion are common steps in the carbonylation of methanol and other synthetically relevant carbonylation reactions. In addition to the full characterization of these complexes in solution and in the solid state, their activity in the alkoxycarbonylation of $\mathrm{C}-\mathrm{H}$ bonds was also tested. On these grounds, we have prepared several binuclear complexes featuring ligands with different donor abilities and metal-ligand bond stabilities $(\mathrm{L}=\mathrm{NHC}$, phosphine, phosphinite and phosphite) in order to evaluate the effect of the ligand system on the catalytic activity.

\section{Results and discussion}

Synthesis and characterization of complexes [Rh( $\mu-\mathrm{KO}, \mathrm{O}^{\prime}$ $\left.\left.\left(\mathrm{CH}_{3}\right)_{2} \mathrm{PO}_{2}\right)(\mathrm{cod})\right]_{2}(1)$ and $\left[\mathrm{Rh}\left(\mu-\mathrm{KO}, \mathrm{O}^{\prime}-\left(\mathrm{CH}_{3}\right)_{2} \mathrm{PO}_{2}\right)(\mathrm{CO})_{2}\right]_{2}(2)$.

Initial synthetic efforts focused on the preparation of a dinuclear rhodium (I) complex featuring two bridging dimethylphosphinate ligands $\left(\left(\mathrm{CH}_{3}\right)_{2} \mathrm{PO}_{2}{ }^{-}\right)$. At first, we attempted a synthetic route that entailed the deprotonation of dimethylphosphinic acid with equimolar amounts of a strong base (potassium tert-butoxide or potassium hexamethyldisilazide) or even weak bases, such as trimethylamine or potassium carbonate, in an organic solvent followed by addition of $[\mathrm{Rh}(\mu-\mathrm{Cl})(\operatorname{cod})]_{2}$. However, this approach failed to cleanly afford the title compound and intractable mixtures were obtained. Subsequently, in order to circumvent the use of an external base, we reacted $[\mathrm{Rh}(\mu-$ $\mathrm{MeO})(\mathrm{cod})]_{2}$ with 2 equivalents of dimethylphosphinic acid in THF at room temperature. This method succeeded to yield complex $1\left(\left[\mathrm{Rh}\left(\mu-\mathrm{KO}, \mathrm{O}^{\prime}-\left(\mathrm{CH}_{3}\right)_{2} \mathrm{PO}_{2}\right)(\mathrm{cod})\right]_{2}\right)$ as a yellow powder in good yields.

The ${ }^{1} \mathrm{H}$ NMR spectrum of 1 at room temperature in $\mathrm{CD}_{2} \mathrm{Cl}_{2}$ shows a broad singlet at $\delta 3.90 \mathrm{ppm}$ and two broad multiplets centered

at $\delta 2.53$ and $1.75 \mathrm{ppm}$ that correspond to the olefinic and aliphatic protons of the 1,5-cyclooctadiene ligand, respectively. A broad doublet at $\delta 1.16 \mathrm{ppm}\left({ }^{2} \mathrm{~J}_{\mathrm{H}-\mathrm{p}}=13.6 \mathrm{~Hz}\right)$ is observed for the methyl groups of the dimethylphosphinate ligand. The ${ }^{13} \mathrm{C}$ NMR spectrum features only one peak for the olefinic carbon atoms, a doublet at $\delta 75.3 \mathrm{ppm}\left({ }^{1} \mathrm{~J}_{\mathrm{C}-\mathrm{Rh}}=14.9 \mathrm{~Hz}\right)$, and only one peak for the methyl groups, a doublet at $\delta 19.3 \mathrm{ppm}\left({ }^{1} \mathrm{~J}_{\mathrm{C}-\mathrm{p}}=\right.$ $104.9 \mathrm{~Hz}$ ).
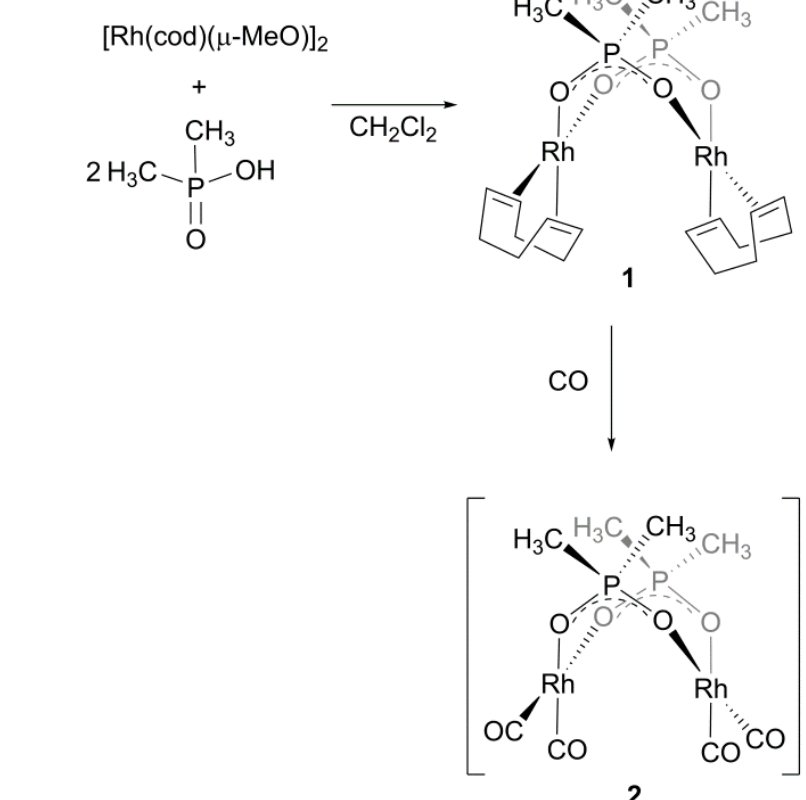

2

Scheme 1 Preparation of complexes 1 and $\mathbf{2}$

Besides, also the aliphatic carbon atoms appear together as a singlet at $31.4 \mathrm{ppm}$. These data may, at first sight, agree with a monomeric formulation of $\mathbf{1}$ since just one type of methyl and olefinic protons are observed. However, the main peak in $\mathrm{ESI}^{+}$ mass spectrometry (of molar mass 609.01) reveals the presence of a fragment that corresponds to a binuclear structure bridged by one dimethylphosphinate ligand, probably originated by loss of a second identical bridge in the ionization process. In addition, the ${ }^{31} \mathrm{P}$ NMR spectrum of complex $\mathbf{1}$ at room temperature shows a broad singlet at $\delta 50.8 \mathrm{ppm}$, which, together with the broad resonances observed in the ${ }^{1} \mathrm{H} N M R$, would suggest a fluxional behavior that casts doubt on the nuclearity of the complex in solution. A plausible explanation would entail a binuclear complex where, at room temperature, all the methyl protons of the dimethylphosphinate ligand become equivalent by means of a fluxional process that turns the binuclear structure inside-out; as a consequence of this transformation the methyl groups in the inner region of the binuclear frame are relocated to the outer region, and vice versa.

Analogously, by the same dynamic process, the inner and outer olefinic protons of the COD ligand become equivalent at room temperature. Similar fluxional processes have been reported for other dinuclear complexes. ${ }^{19}$

The broad singlet at $\delta 50.8 \mathrm{ppm}$ in the ${ }^{31} \mathrm{P}$ NMR spectra of 1 at $293 \mathrm{~K}$ becomes three peaks at $\delta 54.5,53.5$ and $51.7 \mathrm{ppm}$ in a ratio $1: 2: 2.5$ at $193 \mathrm{~K}$ that probably correspond to different 
conformers of an 8-membered ring formed by 2 rhodium, 2 phosphorus and 4 oxygen atoms. Scheme 3 postulates various conformations that complex $\mathbf{1}$ may adopt in solution. In agreement with this postulation, the resonances of the COD and $\mu-\mathrm{KO}, \mathrm{O}^{\prime}-\left(\mathrm{CH}_{3}\right)_{2} \mathrm{PO}_{2}{ }^{-}$ligands in the ${ }^{1} \mathrm{H}$ NMR spectrum resolve at $193 \mathrm{~K}$ into several (still) broad peaks. The broad peak at $\delta 3.90$ ppm assigned to the olefinic protons at $193 \mathrm{~K}$ becomes three broad singlets at $\delta 3.95,3.74$ and $3.68 \mathrm{ppm}$ at $193 \mathrm{~K}$. The broad doublet at $1.16 \mathrm{ppm}$ at $293 \mathrm{~K}$ turns into three doublets at $\delta 1.34$ $\left({ }^{2} \mathrm{~J}_{\mathrm{H}-\mathrm{P}}=14.0 \mathrm{~Hz}\right), 1.21\left({ }^{2} \mathrm{~J}_{\mathrm{H}-\mathrm{P}}=13.6 \mathrm{~Hz}\right)$ and $1.00\left({ }^{2} \mathrm{~J}_{\mathrm{H}-\mathrm{P}}=13.7 \mathrm{~Hz}\right)$ ppm. Noteworthy, there is no apparent relationship between the integration of the olefinic protons and methyl groups or to the ratio found in the ${ }^{31} \mathrm{P} N \mathrm{NMR}$, probably due to the existence of an intricate mixture of conformers interconverting in solution together with the dissymmetric nature of some of them.

The binuclear structure of complex 1 in the solid state was confirmed by single crystal X-ray diffraction (Fig. 1). Crystals were obtained by slow diffusion of pentane into a saturated dichloromethane solution. The molecular structure of 1 shows two crystallographically inequivalent rhodium atoms, which are two-fold bridged by two dimethylphosphinate ligands. Interatomic Rh1-Rh2 separation is of 3.8923(6) $\AA$, far from exhibiting any kind of intermetallic interaction. The
$\mathrm{Rh}\left\{\left(\mathrm{CH}_{3}\right)_{2} \mathrm{PO}_{2}\right\}_{2} \mathrm{Rh}$ central fragment adopts a pseudo-boat conformation. Both $\left(\mathrm{CH}_{3}\right)_{2} \mathrm{PO}_{2}$ ligands are twisted by 16.90 and 29.70 (O-Rh-Rh-O), whereas torsion angles involving the cod ligands display related values: 16.1 o and 30.5 ( $\mathrm{C}-\mathrm{Rh}-\mathrm{Rh}-\mathrm{C})$. The coordination sphere of the square-planar metals is completed by a classical cis positioning of the cod ligands. The reaction of 1 with carbon monoxide (1 atm) at room temperature leads to the formation of biscarbonyl complex 2 $\left(\left[\mathrm{Rh}\left(\mu-\mathrm{KO}, \mathrm{O}^{\prime}-\left(\mathrm{CH}_{3}\right)_{2} \mathrm{PO}_{2}\right)(\mathrm{CO})_{2}\right]_{2}\right)$ and concomitant release of $1,5-$ cyclooctadiene.

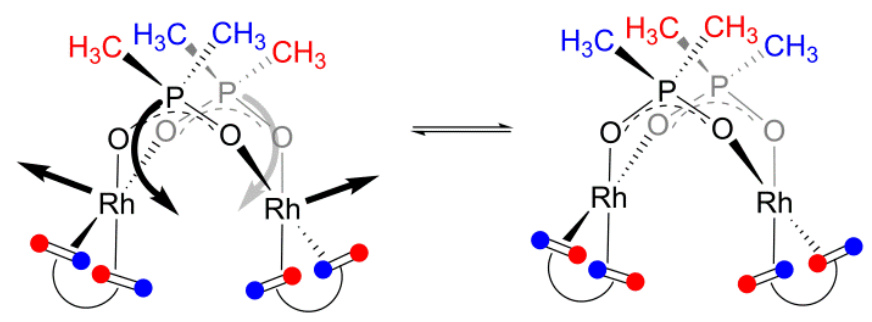

Scheme $\mathbf{2}$ Depiction of the proposed "inside-out mechanism" for complex $\mathbf{1}$
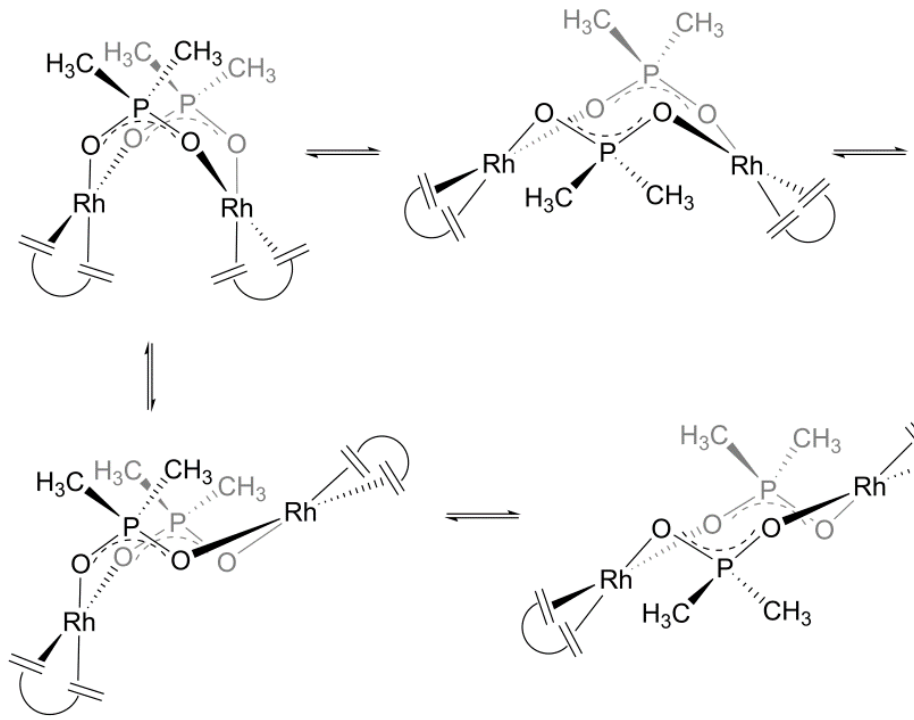

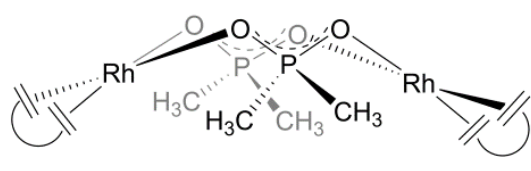

$\Upsilon 广=1,5$-Cyclooctadiene

Scheme 3 Possible conformations of 1 in solution.

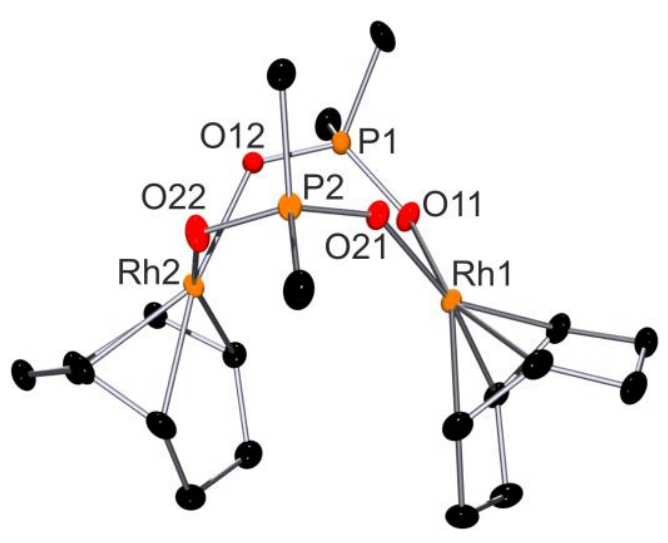

Fig. 1 View of the dimer $\left[\mathrm{Rh}\left(\mu-\mathrm{KO}, \mathrm{O}^{\prime}-\left(\mathrm{CH}_{3}\right)_{2} \mathrm{PO}_{2}\right)(\operatorname{cod})\right]_{2}(\mathbf{1})$. Selected bond distances $[\AA \AA]$ and angles []: Rh1-011, 2.105(3); Rh1-021, 2.089(3); Rh1-C31, 2.084(4); Rh1-C32, 2.077(4); Rh1-C35, 2.109(4); Rh1-C36, 2.086(4); Rh2-O12, 2.089(3); Rh2-O22, 2.076(3); Rh2-C41, 2.099(4); Rh2-C42, 2.074(4); Rh2-C45, 2.106(4); Rh2-C46, 2.088(4). O21Rh1-011, 90.66(11); O22-Rh2-012, 88.65(12).

Attempts to isolate complex $\mathbf{2}$ were unsuccessful due to the loss of carbonyl ligands under vacuum or when placed in an argon atmosphere. However, complex $\mathbf{2}$ was successfully characterized in situ by NMR spectroscopy. The ${ }^{1} \mathrm{H}$ NMR spectrum in $\mathrm{CH}_{2} \mathrm{Cl}_{2}$ of 2 shows only a doublet $\left({ }^{2} \mathrm{~J}_{\mathrm{H}-\mathrm{P}}=13.9 \mathrm{~Hz}\right)$ at $\delta 1.40 \mathrm{ppm}$, which was assigned to the methyl protons. The ${ }^{13} \mathrm{C}$ NMR shows the peaks that correspond to the methyl groups of the dimethylphosphinate ligand at $\delta 17.5 \mathrm{ppm}$ as a doublet $\left({ }^{1} \mathrm{~J}_{\mathrm{C}}\right.$ $\mathrm{p}=98.1 \mathrm{~Hz}$ ) and those of the carbonyl ligands at $\delta 182.4 \mathrm{ppm}$ as 
a doublet as well $\left({ }^{1} \mathrm{~J}_{\mathrm{C}-\mathrm{Rh}}=40.5 \mathrm{~Hz}\right)$. The ${ }^{31} \mathrm{P} \mathrm{NMR}$ is slightly modified upon substitution of the COD ligand, featuring a sharp singlet at $\delta 59.3 \mathrm{ppm}$.

In contrast to the fluxional behavior of $\mathbf{1}$, sharp resonances are observed at room temperature in the ${ }^{1} \mathrm{H}$ and ${ }^{31} \mathrm{P}$ NMR spectra, which do not undergo any apparent modification at low temperature. This may be rationalized as a consequence of the lower energy barriers between conformers in 2, which may be due to the reduced steric hindrance of the $\mathrm{CO}$ ligands compared to the COD ligand in $\mathbf{1}$, as well as the greater geometrical constraints imposed by the chelating nature of the COD ligand in 1.

Synthesis and characterization of complexes [Rh( $\mu-\mathrm{kO}, \mathrm{O}^{\prime}$ $\left.\left.\left(\mathrm{CH}_{3}\right)_{2} \mathrm{PO}_{2}\right)(\mathrm{CO}) \mathrm{L}\right]_{2}$ (5a-d).

At the outset, the reactivity of $\mathbf{2}$ with ligands featuring different donating abilities ( $L=1,3$-bis(2,6-diisopropylphenyl)imidazol-2ylidene (IPr), $\mathrm{PPh}_{3}, \mathrm{P}(\mathrm{OMe}) \mathrm{Ph}_{2}$ and $\mathrm{P}(\mathrm{OPh})_{3}$ ) was tested in the search for binuclear complexes where one of the carbonyl ligands at the rhodium center would be substituted by the ancillary ligand (L). This would allow us to optimize the activity of the catalyst by tuning the electron density at the metal center. Although this synthetic method afforded the expected complexes, the substantial amount of byproducts thus obtained led to intractable mixtures of complexes. Among the above mentioned byproducts we identified the formation of the cation $\left[\mathrm{Rh}\left(\mathrm{PPh}_{3}\right)_{2}(\mathrm{CO})_{2}\right]^{+}$probably due the presence of two labile positions in $\mathbf{2}$, the bridge and the second carbonyl ligand, that can be occupied by 2 equivalents of the phosphine ligand. Therefore, complexes 3a-d ([Rh $\left.\left.\left(\mathrm{KO}-\left(\mathrm{CH}_{3}\right)_{2} \mathrm{PO}_{2}\right)(\mathrm{COD})(\mathrm{L})\right]\right)$ were prepared in situ as synthetic intermediates in order to achieve a better control over the stoichiometry of the reaction. Subsequently, the reactivity of these complexes with carbon monoxide was studied. The reaction of $\mathbf{3 b} \mathbf{b} \mathbf{d}$ with carbon monoxide (1 atm) at room temperature promoted the selfassembly of dimeric complexes $\mathbf{5 b}$-d, which were obtained as yellow solids after evaporation of the solvent. Conversely, in the case of the IPr ligand, complex 4 ([Rh $\left.\left.\left(\mathrm{KO}-\left(\mathrm{CH}_{3}\right)_{2} \mathrm{PO}{ }_{2}\right)(\mathrm{CO})_{2} \mathrm{IPr}\right]\right)$ was obtained instead of the expected binuclear entity, probably due to the higher electron density at the metal center in 3a compared to $\mathbf{3 b} \mathbf{b}-\mathbf{d}$, which results in a stronger coordination of the carbonyl ligand as a result of an enhanced $\pi$-backdonation.
In order to abstract one of the carbonyl ligands, 4 was treated with trimethylamine $\mathrm{N}$-oxide, which gives $\mathbf{5 a}$ as a yellow solid together with trimethylamine and carbon dioxide as reaction by-products, both being easily eliminated by placing the reaction mixture under vacuum (Scheme 4).

The ${ }^{1} \mathrm{H}$ NMR spectrum of 4 reveals a two-fold symmetry for the IPr ligand, probably due to its free rotation about the $\mathrm{C}-\mathrm{Rh}$ bond. The methyl groups of the phoshinate ligand appear as one doublet at $\delta 0.8 \mathrm{ppm}\left({ }^{2} \mathrm{~J}_{\mathrm{H}-\mathrm{P}}=13.5 \mathrm{~Hz}\right)$. The most notable resonances in the ${ }^{13} \mathrm{C}$ NMR spectra of 4 are those of the two carbonyl ligands at $\delta 185.3$ and $184.3 \mathrm{ppm}$, which appear as doublets due to coupling with the rhodium centers, 69.2 and $62.1 \mathrm{~Hz}$, respectively. The presence of two carbonyl ligands in complex $\mathbf{4}$ is supported by the two strong bands observed at 1984 and $1935 \mathrm{~cm}^{-1}$ in the infrared spectra. The global connectivity pattern of complex 4 was confirmed by single crystal X-ray diffraction. Crystals were obtained by slow diffusion of pentane into a saturated dichloromethane solution. Coordination about the central $\mathrm{Rh}(\mathrm{I})$ ion of compound 4 encloses an IPr ligand, a dimethylphosphinate anion and two cis-positioned $\mathrm{CO}$ entities (Fig. 2). It is worth mentioning the longer $\mathrm{Rh}-\mathrm{C}$ distance exhibited by the carbonyl ligand trans positioned to the IPr entity (Rh1-C2, 1.913(2) $\AA$ ), in comparison to its partner, trans to the $\left(\mathrm{CH}_{3}\right)_{2} \mathrm{PO}_{2}$ anion (Rh1-C1, 1.8169(19) $\AA$ )), probably due to the higher trans influence of the NHC ligand. The reaction of $\mathbf{4}$ with 1 equivalent of trimethylamine $\mathrm{N}$-oxide generates a vacant coordination site that can be occupied by the second oxygen atom of the dimethylphosphinate ligand, which acts as a bridging ligand in complex 5a. The infrared spectra of complex 5a suggests the abstraction of one of the carbonyl ligands from complex 4 as only one band at $1948 \mathrm{~cm}^{-1}$ is observed.

When compared with 4 , the ${ }^{1} \mathrm{H}$ NMR spectra of $\mathbf{5 a}$ in $\mathrm{CD}_{2} \mathrm{Cl}_{2}$ present only slight differences in the chemical shifts. The ${ }^{13} \mathrm{C}$ NMR spectra, on the other hand, show the disappearance of one of the carbonyl ligands, thus supporting the information obtained from the IR spectra. $\mathrm{ESI}^{+}$Mass spectrometry corroborates the binuclear structure of $\mathbf{5 a}$ since it shows a main peak that matches with the molar mass of $\mathbf{5 a}$ without a dimethylphosphinate ligand, analogously to complex 1 .

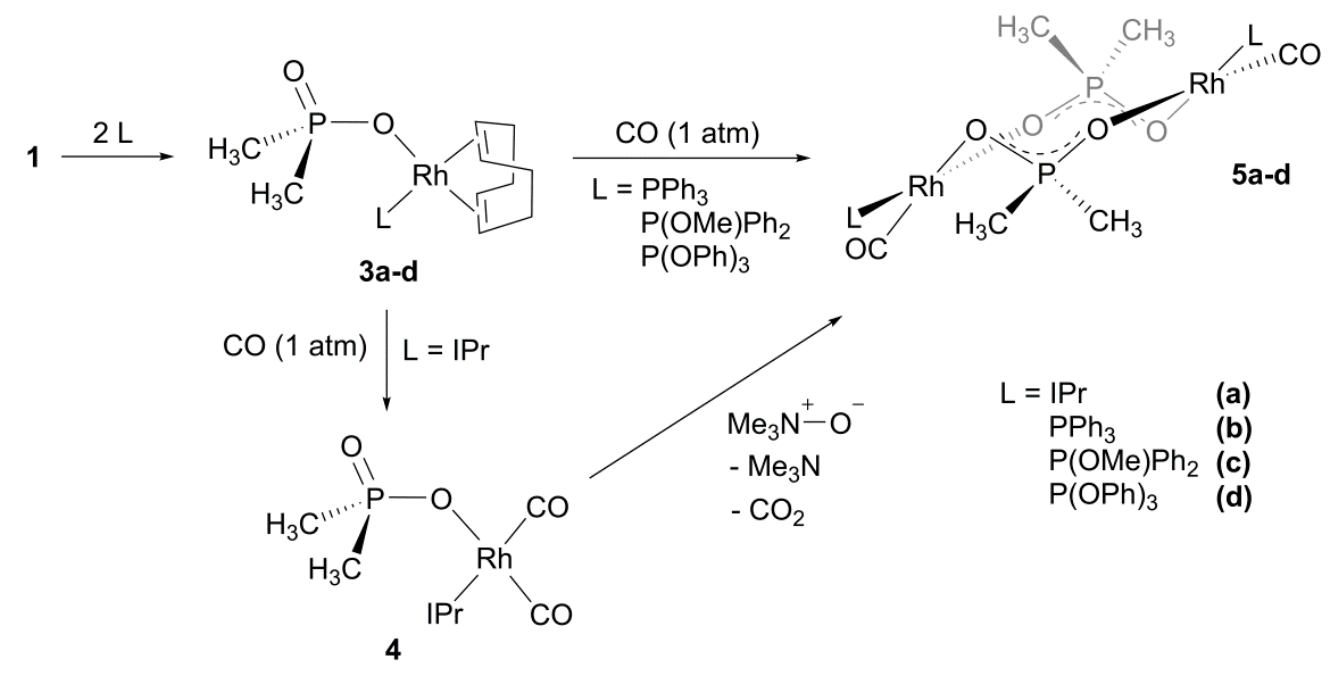




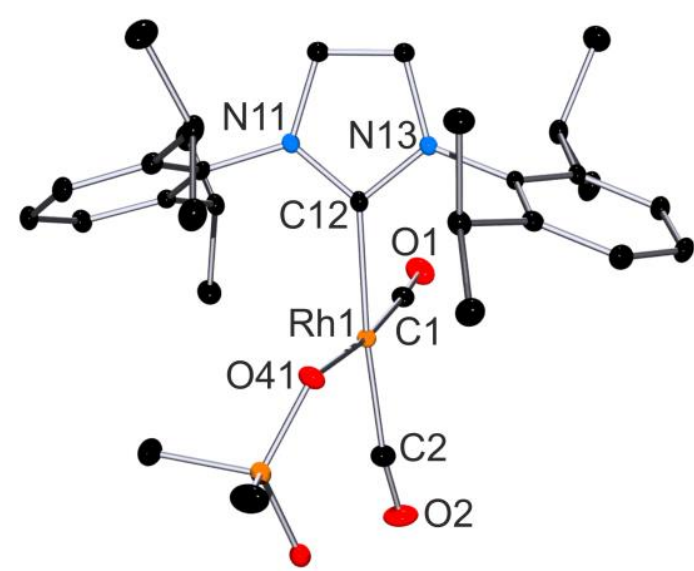

Fig. 2. View of $\left[\mathrm{Rh}\left(\mathrm{KO}-\left(\mathrm{CH}_{3}\right)_{2} \mathrm{PO}_{2}\right)(\mathrm{CO})_{2}(\mathrm{IPr})\right](4)$. Selected bond distances $[\AA ̊]$ and angles [0]: Rh1-C1, 1.8169(19); Rh1-C2, 1.913(2); Rh1-O41, 2.0488(13); Rh1-C12, 2.0679(18); C1-Rh1-C2, 88.11(9); C1-Rh1-O41, 173.87(8); C2-Rh1-041, 96.67(7); C1-Rh1-C12, 85.18(8); C2-Rh1-C12, 172.77(8); O41-Rh1-C12, 90.21(6).

The expected binuclear connectivity of compound 5a was confirmed by X-ray crystallography. Single crystals of $5 \mathrm{a} \cdot 2 \mathrm{CH}_{2} \mathrm{Cl}_{2}$ were obtained by slow diffusion of pentane into a saturated dichloromethane solution.

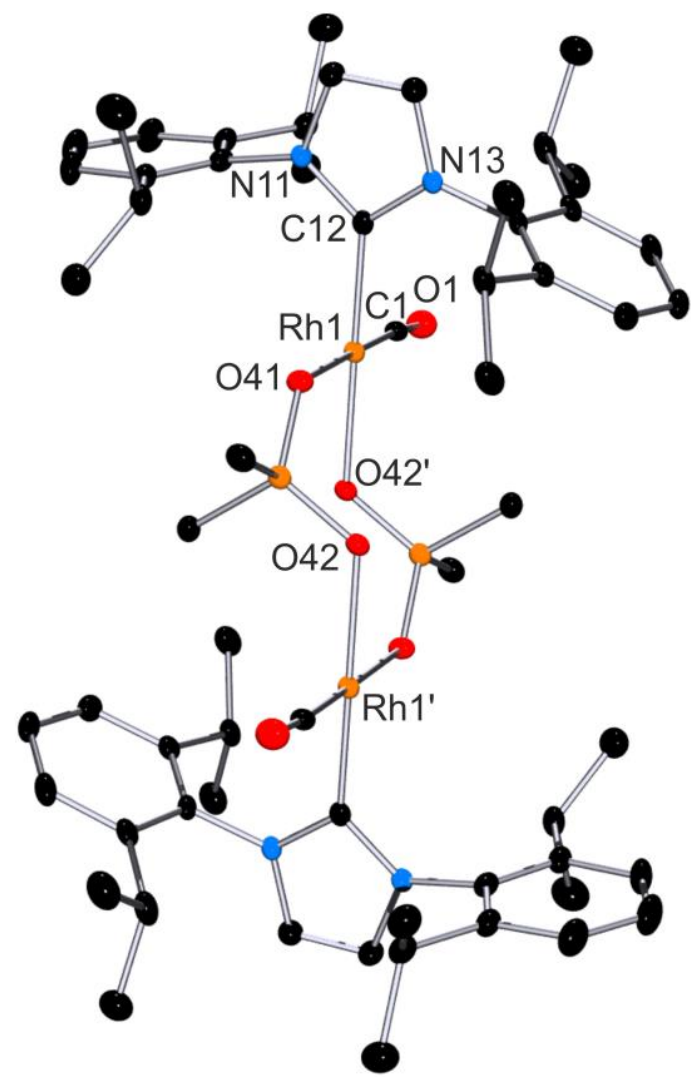

Fig. 3. Side view of the dimer $\left[\mathrm{Rh}\left(\mu-\mathrm{KO}, \mathrm{O}^{\prime}-\left(\mathrm{CH}_{3}\right)_{2} \mathrm{PO}_{2}\right)(\mathrm{CO})(\mathrm{IPr})\right]_{2} \cdot 2 \mathrm{CH}_{2} \mathrm{Cl}_{2}\left(5 \mathbf{a} \cdot 2 \mathrm{CH}_{2} \mathrm{Cl}_{2}\right)$. Selected bond distances [Å] and angles [ㅇ]: Rh1-C1, 1.786(3); Rh1-C12, 1.972(3); Rh1O41, 2.086(2); Rh1-O42, 2.109(2); C1-Rh1-C12, 93.63(12); C1-Rh1-O41, 177.92(12); C12-Rh1-041, 88.17(10); C1-Rh1-042, 91.10(11); C12-Rh1-042, 174.82(10); O41Rh1-042, 87.15(8); O1-C1-Rh1, 175.1(3).
As shown in Fig. 3, the crystallographically centrosymmetric structure of 5 a consists of a central fragment $\operatorname{Rh}\left\{\left(\mathrm{CH}_{3}\right)_{2} \mathrm{PO}_{2}\right\}_{2} \mathrm{Rh}$, which, at variance with $\mathbf{1}$, exhibits a pseudo-chair conformation (Rh1-Rh1', 5.2473(5) A). The Rh1 ions further coordinate a CO and an IPr ligand. Bond distances and angles within the coordination sphere of the rhodium atom are as expected and differ only slightly if compared to $\mathbf{1}$. Noteworthy, the IPr ligands at both rhodium atoms are situated in mutual anti position, probably due to the fact that this isomer is less sterically hindered than the one arising from the syn conformation.

Complex $\mathbf{3} \mathbf{b}$ was transformed into $\mathbf{5 b}$ by reaction with carbon monoxide. In contrast with $\mathbf{3 a}$, in this case the biscarbonyl complex analogous to $\mathbf{4}$ is not isolated and, presumably by loss of a CO ligand, affords directly the binuclear complex (5b).

The ${ }^{1} \mathrm{H}$ NMR spectra of $\mathbf{5} \boldsymbol{b}$ in $\mathrm{CD}_{2} \mathrm{Cl}_{2}$ show as most representative resonance that corresponding to the methyl groups of the bridging ligands at $\delta 0.98 \mathrm{ppm}$, which appears as a doublet due to coupling with the phosphorus atom $\left({ }^{2} \mathrm{~J}_{\mathrm{H}-\mathrm{P}}=14.2 \mathrm{~Hz}\right)$. The ${ }^{13} \mathrm{C}$ NMR spectra present a doublets of doublets for the carbonyl ligands at $\delta 189.7 \mathrm{ppm}$ due to coupling with the rhodium center $\left({ }^{1} \mathrm{~J}_{\mathrm{C}-\mathrm{Rh}}=77.1 \mathrm{~Hz}\right)$ and the triphenylphosphane ligand $\left({ }^{2} \mathrm{~J}_{\mathrm{C}-\mathrm{P}}=23.3\right.$ $\mathrm{Hz})$, and a doublet at $\delta 18.3 \mathrm{ppm}$ for the methyl group $\left({ }^{1} \mathrm{~J}_{\mathrm{C}-\mathrm{p}}=98\right.$ $\mathrm{Hz}$ ) as the most characteristic resonances.

The two chemically inequivalent phosphorus nuclei of the two bridging dimethylphosphinate ligands are observed in the ${ }^{31} \mathrm{P}$ NMR spectra as a singlet at $\delta \quad 52.4 \mathrm{ppm}$ while the triphenylphosphine ligands are observed as a doublet $\left({ }^{1} \mathrm{~J}_{\mathrm{P}-\mathrm{Rh}}=\right.$ $181.5 \mathrm{~Hz}$ ) at $\delta 47.9 \mathrm{ppm}$.

Infrared spectroscopy shows a single band for the CO ligands at $1960 \mathrm{~cm}^{-1}$ and mass spectrometry $\left(\mathrm{ESI}^{+}\right)$shows a main peak of mass 878.9976 that corresponds to a binuclear complex with only one dimethylphosphinate bridge. The high symmetry observed in solution needs to be explained again by invoking the "inside-out mechanism" previously described for complex 1.

Analogously to $\mathbf{5 b}$, complexes $\mathbf{5 c}$ and $\mathbf{5 d}$ were obtained directly by reaction with carbon monoxide of the mononuclear complexes $\mathbf{3 c}$ and $\mathbf{3 d}$, respectively. The ${ }^{1} \mathrm{H}$ NMR spectra of $\mathbf{5 c}$ and $\mathbf{5 d}$ do not show remarkable differences compared to $\mathbf{5 b}$ concerning the bridging ligand. The fact that the methyl groups appear as doublets at $\delta 1.05$ and 0.87 ppm, respectively, suggests a fluxional behavior similar to that presented by binuclear complexes $\mathbf{1}, \mathbf{5 a}$ and $\mathbf{5 b}$, which renders the protons of the inner and outer methyl groups equivalent. The ${ }^{31} \mathrm{P} N M R$ spectra of $\mathbf{5 c}$ and $\mathbf{5 d}$ feature only one peak for the two equivalent phosphorus atoms of the bridging ligands and another peak for the phosphinite or phosphite ligands, the latter appear at $\delta 135.0$ and $117.6 \mathrm{ppm}$ while the former show resonances at $\delta 52.5$ and $53.9 \mathrm{ppm}$, respectively.

The binuclear nature of both complexes was confirmed by ESI ${ }^{+}$ mass spectrometry and infrared spectroscopy. The $\mathrm{MS}\left(\mathrm{ESI}^{+}\right)$ spectra of $\mathbf{5 c}$ and $\mathbf{5 d}$ show as main peak the mono-bridged complexes in both cases. In agreement with the information obtained by mass spectrometry, the IR spectra of $\mathbf{5 c}$ and $\mathbf{5 d}$ 
present only one carbonyl vibration band at 1962 and $1987 \mathrm{~cm}^{-}$ 1 , respectively.

Compound $\mathbf{5 c}$ was crystallized by slow diffusion of pentane into a solution of $\mathbf{5 c}$ in dichlorometane. Fig. 4 shows the centrosymmetric arrangement of $\mathbf{5 c}$.

The central $\operatorname{Rh}\left\{\left(\mathrm{CH}_{3}\right)_{2} \mathrm{PO}_{2}\right\}_{2} \mathrm{Rh}$ fragment shows a pseudo-boat conformation with an intermetallic Rh1-Rh1' distance of 3.9440(3) A. Here, in addition to the $\left(\mathrm{CH}_{3}\right)_{2} \mathrm{PO}_{2}$ bridges, Rh1 coordinates a $\mathrm{CO}$ and a $\mathrm{P}(\mathrm{OMe}) \mathrm{PPh}_{2}$ ligand. The torsion angles displayed by the $\left(\mathrm{CH}_{3}\right)_{2} \mathrm{PO}_{2}-$ bridges are more pronounced than in the case of 1 , exhibiting values of 31.2 and 37.2 . This facilitates the mutual positioning of the phenyl entities.

Both $\mathrm{Rh}-\mathrm{O}$ distances are within the same range (Rh1-O21, 2.0749(13); Rh1-022, 2.0988(13) A). Analogously to the solid state structure of $\mathbf{5 a}$, the phosphinite ligands at both metal centers in $\mathbf{5 c}$ are in mutual anti positions.

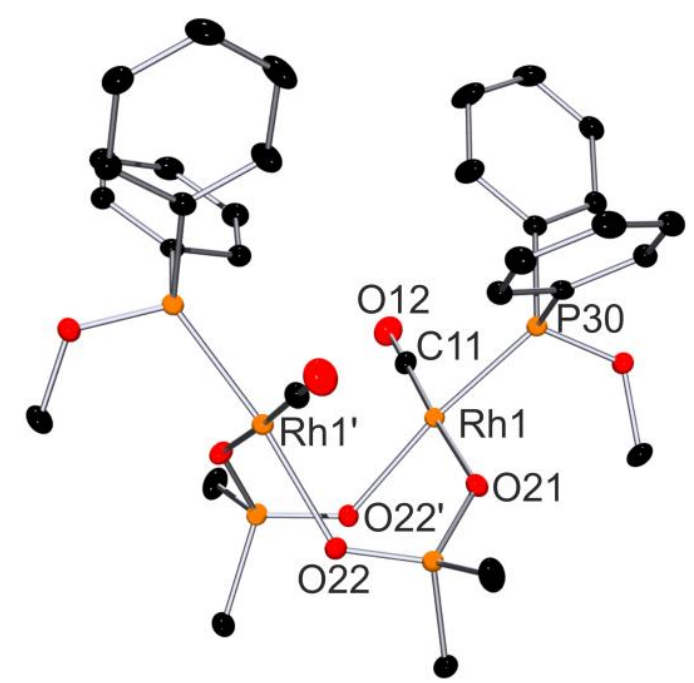

Fig. 4. Side view of the dimer $\left[\mathrm{Rh}\left(\mu-\mathrm{KO}, \mathrm{O}^{\prime}-\left(\mathrm{CH}_{3}\right)_{2} \mathrm{PO}_{2}\right)(\mathrm{CO})\left(\mathrm{P}(\mathrm{OMe}) \mathrm{Ph}_{2}\right)\right]_{2} \cdot 2 \mathrm{CH}_{2} \mathrm{Cl}_{2}$ (5c. $2 \mathrm{CH}_{2} \mathrm{Cl}_{2}$ ). Selected bond distances [Å] and angles [0]: Rh1-C11, 1.793(2); Rh1-O21, 2.0749(13); Rh1-O22, 2.0988(13); Rh1-P30, 2.1953(5); C11-Rh1-O21, 177.24(7); C11Rh1-O22, 94.80(7); O21-Rh1-O22, 87.35(5); C11-Rh1-P30, 90.07(7); O21-Rh1-P30, 87.63(4); O22-Rh1-P30, 172.97(4).

However, in this case, the release of steric hindrance achieved upon changing the IPr by the $\mathrm{P}(\mathrm{OMe}) \mathrm{Ph}_{2}$ ligand results in the adoption of a pseudo-boat conformation of the $\mathrm{Rh}\left\{\left(\mathrm{CH}_{3}\right)_{2} \mathrm{PO}_{2}\right\}_{2} \mathrm{Rh}$ fragment in $\mathbf{5 c}$. The same behavior is observed in the solid state structure of $\mathbf{1}$, which suggests that the pseudo-boat is more thermodynamically stable than its related pseudo-chair conformation. In this regard, it may be postulated that the higher intra-ring strain or stronger attractive Van der Waals interactions in the pseudo-chair conformation impose this conformation as long as the steric repulsion between the ligands $(\mathrm{L})$ at the $\mathrm{Rh}$ centers does not become prevalent. Although this postulation might seem counter-intuitive since chair conformations are usually less strained structures than their related boat conformations, in this case the intra-ring repulsions originated by the oxygen nonbonding pairs of electrons and the methyl groups of the dimethylphosphinate bridges seem to be significantly reduced in the latter. A similar behavior has been described for other 8membered ring dinuclear complexes containing two square planar Pd(II) complexes. ${ }^{20}$
Catalysis.

The alkoxycarbonylation of 2-(2-thienyl)pyridine with $n$ hexanol, carbon monoxide ( $2 \mathrm{~atm}$ ) and excess oxone as oxidant

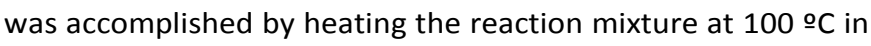
toluene for $18 \mathrm{~h}$, according to a similar procedure reported in the literature to afford the new organic ester hexyl-2-(pyridin2-yl)thiophene-3-carboxylate (Scheme 5). ${ }^{8 a}$

With the purpose of shedding light on the influence of the ligand system on the catalytic activity of $\mathrm{Rh}(\mathrm{I})$ complexes in the alkoxycarbonylation of $\mathrm{C}-\mathrm{H}$ bonds, complexes $\mathbf{1}$ and $\mathbf{5 a - d}$ were tested in a comparative study.

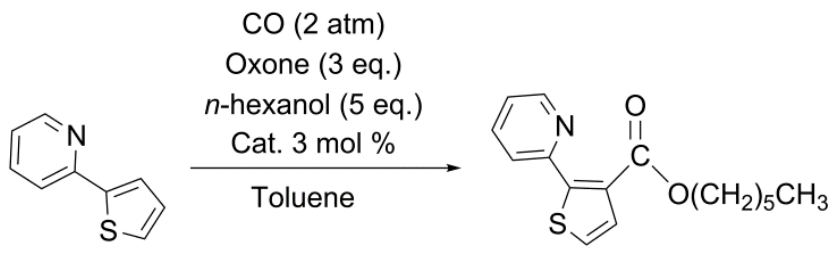

Scheme 5 Alkoxycarbonylation of 2-(2-thienyl)pyridine.

It is worth mentioning that the CO vibration frequency in the IR spectra of complexes $\mathbf{5 a}, \mathbf{5} \mathbf{b}, \mathbf{5} \mathbf{c}$ and $\mathbf{5} \mathbf{d}$ and the donor ability of the ligands (L) show a clear trend, $v=1948$ (5a), 1960 (5b), 1962 (5c) and $1987(5 d) \mathrm{cm}^{-1}$, the values of the Tolman electronic parameter (TEP) for IPr, $\mathrm{PPh}_{3}, \mathrm{P}(\mathrm{OMe}) \mathrm{Ph}_{2}$ and $\mathrm{P}(\mathrm{OPh})_{3}$ being 2051, 2069, 2072 and 2085, respectively. ${ }^{21}$ The fact that higher vibration frequencies indicate lower electron densities at the metal center suggests that the activity of the catalyst could be optimized by employing ancillary ligands with different $\sigma$ donating abilities. However, the activity trend shows a more intricate behavior (Table 1), where other factors could play a decisive role.

Complex 1 shows a catalytic activity comparable to $[\mathrm{Rh}(\mu-$ $\mathrm{Cl})(\mathrm{cod})]_{2}$, the only rhodium catalyst hitherto reported for this reaction. ${ }^{8}$ In the case of complex 5a, were one of the carbonyl ligands was exchanged by IPr, the activity of the catalyst suffers a substantial decrease. This result may be rationalized in terms of the robust $\mathrm{Rh}-\mathrm{NHC}$ bond, ${ }^{22}$ which blocks the coordination site where the labile second carbonyl ligand would be in $\mathbf{1}$ (Scheme 6). The presence of the second carbonyl ligand may be crucial to permit a rapid migratory insertion of the $\mathrm{CO}$ into the $\mathrm{Rh}-\mathrm{C}$ bond. This effect has been previously interpreted in the literature as a consequence of the increased electrophilicity of the carbonyl carbon atom, due to a reduced $\pi$-backdonation resulting from the competition with the other $\mathrm{CO}$ ligands at the metal center for the d electrons. ${ }^{23}$

NHCs ligands have been reported to facilitate the cyclometalation step ${ }^{24}$ but, in this case, probably hamper $\mathrm{CO}$ coordination because the position of the second carbonyl ligand would be occupied by the strongly coordinating NHC. In addition, the remaining $\mathrm{CO}$ ligand is further deactivated toward migratory insertion owing to the enhanced $\pi$-backdonation from the electron rich metal center, due to the strongly donating ability of the IPr ligand. 
Table 1 Alkoxycarbonylation of 2-(2-thienyl)pyridine with n-hexanol, carbon monoxide and oxone.

\begin{tabular}{ccc}
\hline Entry & Pre-catalyst & Yield (\%) \\
\hline 1 & {$[\mathrm{Rh}(\mu-\mathrm{Cl})(\mathrm{cod})]_{2}$} & 84 \\
2 & $\mathbf{1}$ & 91 \\
3 & $\mathbf{5 a}$ & 35 \\
4 & $\mathbf{5 b}$ & 77 \\
5 & $\mathbf{5 c}$ & 55 \\
6 & $\mathbf{5 d}$ & 64 \\
\hline
\end{tabular}

Conditions: 2,2-Thienylpiridyne $(0.2 \mathrm{mmol}, 32 \mathrm{mg}), \mathrm{n}$-hexanol $(1 \mathrm{mmol}$, $125 \mu \mathrm{L})$, oxone $(0.6 \mathrm{mmol}, 184 \mathrm{mg})$, mesitylene ( $50 \mu \mathrm{L}, 0.36 \mathrm{mmol})$ catalyst ( $2 \mathrm{~mol} \%)$ and CO (2 atm) in toluene $(4 \mathrm{~mL}), 100$ ㅇ C for $18 \mathrm{~h}$.

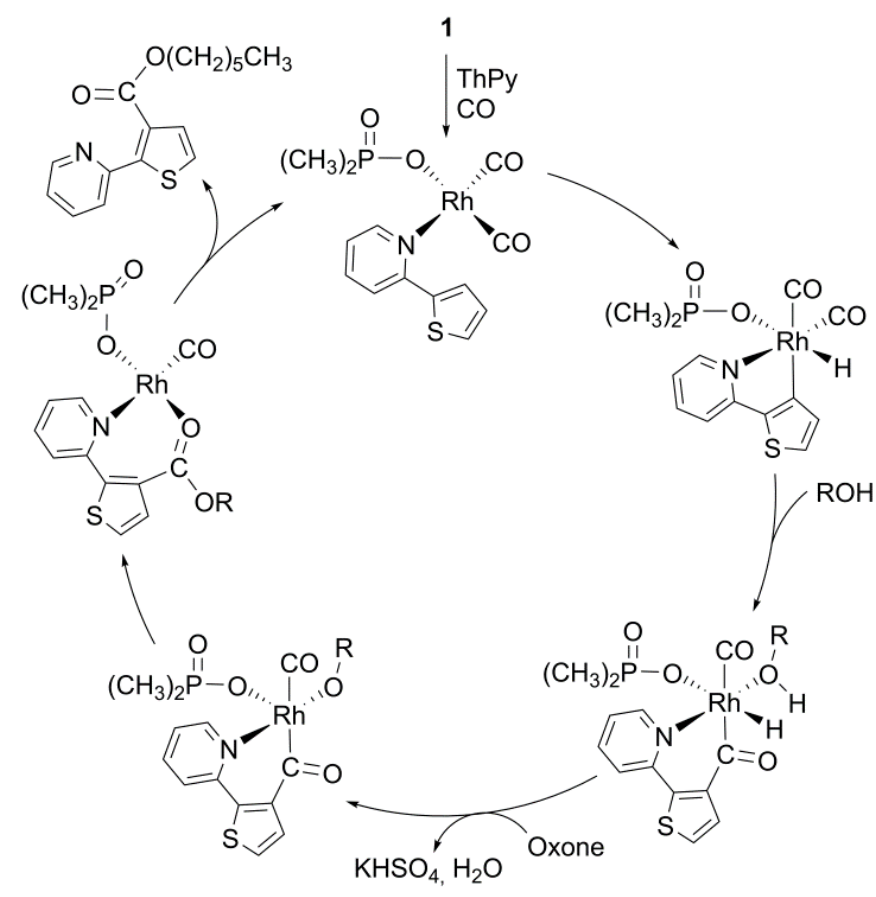

Scheme 6. Proposed catalytic cycle for the alkoxycarbonylation of 2-(2-thienyl)pyridine using pre-catalyst 1 based on Zhang's studies. ${ }^{8 a}$

The use of a phosphine, phosphinite or phosphite ligand improves the yield of alkoxycarbonylation compared to IPr. However, the lower yields obtained for precatalysts $\mathbf{5 b}-\mathbf{d}$ compared to $\mathbf{1}$ and $[\mathrm{Rh}(\mu-\mathrm{Cl})(\operatorname{cod})]_{2}$ suggest again that the presence of $\sigma$-donating ligands reduces the activity of the catalyst.

The tendency of complexes $\mathbf{5 b}$-d to undergo the cyclometalation step would be reduced compared to $\mathbf{1}$, owing to the reduced electron density at the Rh center (vide supra). On the other hand, NHCs give rise to stronger Rh-L bonds than phosphorus-donor ligands, ${ }^{25}$ which would facilitate the coordination a second $\mathrm{CO}$ ligand. Therefore, the higher activity observed for weaker electron-donating and less coordinating ligands agrees with the migratory insertion step being the rate limiting step as previously proposed by Zhang et al..8a

The relative differences in activity between phosphorus-donor ligands in $\mathbf{5 b}$-d are, in principle, difficult to explain based merely on the $\sigma$-donating ability of the ligand or the stability of the Rh$\mathrm{P}$ bond. The oxidation of the phosphorus-donor ligands in the presence of oxone, triphenylphosphine being the most easily oxidized, ${ }^{26}$ or simply the experimental error in the measurements of the yields might be plausible explanations.

\section{Conclusions}

An efficient synthetic methodology for the preparation of a variety of binuclear $\mathrm{Rh}(\mathrm{I})$ complexes with dimethylphosphinate bridging ligands has been disclosed. This method permits the preparation of binuclear complexes containing $\mathrm{NHC}$ and phosphine ligands $\left(\left[\mathrm{Rh}\left(\mu-\mathrm{kO}, \mathrm{O}^{\prime}-\left(\mathrm{CH}_{3}\right)_{2} \mathrm{PO}_{2}\right)(\mathrm{CO}) \mathrm{L}\right]_{2}\right)$, and opens the door to a range of related complexes featuring new ligands (L). Fine tuning of the electron density at the metal center can be achieved by the use of ligands with different electron donating abilities.

The activity of the pre-catalysts reported in this work in the alkoxycarbonylation of 2-(2-thienyl)pyridine with $n$-hexanol is related with the ability of the Rh center to coordinate a second carbonyl ligand. Such behavior is likely due to the fact that the coordination of a second CO ligand to give complex $\mathbf{2}$ makes the carbonyl carbon atom more electrophilic and, therefore, more susceptible toward alryl migration. In fact, the most active precatalysts tested in this work are $[\mathrm{Rh}(\mu-\mathrm{Cl})(\operatorname{cod})]_{2}$ and complex $\mathbf{1}$, both featuring COD ligands, which are easily displaced by carbon monoxide under catalytic conditions to afford the corresponding dimeric carbonyl complex. Therefore, on the lookout for more active alkoxycarbonylation catalysts, the results presented in this work suggest that carbonyl complexes featuring electron-poor metal centers are more prone to catalyze this reaction.

\section{Experimental}

General Considerations. All experiments were carried out under an inert atmosphere by using standard Schlenk techniques. The solvents were dried by known procedures and distilled under argon prior to use or obtained oxygen- and water-free from a Solvent Purification System (Innovative Technologies). The starting complexes $[\operatorname{Ir}(\mathrm{COD})(\mu-\mathrm{Cl})]_{2}$ and $[\operatorname{Ir}(\mu-$ $\mathrm{OMe})(\mathrm{COD})]_{2}$ were prepared according to a literature procedure. ${ }^{27}$ All other chemicals were used as purchased from Sigma-Aldrich, Merck and J. T. Baker. CO gas (>99.5 \%) was obtained from Infra. ${ }^{1} \mathrm{H},{ }^{13} \mathrm{C}\left\{{ }^{1} \mathrm{H}\right\}$ and ${ }^{31} \mathrm{P}$ spectra were recorded either on a Bruker ARX $300 \mathrm{MHz}$ or a Bruker Avance $400 \mathrm{MHz}$ instruments. Chemical shifts (expressed in parts per million) are referenced to residual solvent peaks $\left({ }^{1} \mathrm{H},{ }^{13} \mathrm{C}\left\{{ }^{1} \mathrm{H}\right\}\right)$ and to an external reference of $\mathrm{H}_{3} \mathrm{PO}_{4}$ for ${ }^{31} \mathrm{P}\left\{{ }^{1} \mathrm{H}\right\}$. Coupling constants, J, are given in $\mathrm{Hz}$. Spectral assignments were achieved by combination of ${ }^{1} \mathrm{H}-{ }^{1} \mathrm{H}$ COSY, ${ }^{13} \mathrm{C}$ APT and ${ }^{1} \mathrm{H}-{ }^{13} \mathrm{C}$ HSQC/HMBC experiments. $\mathrm{C}, \mathrm{H}$, and $\mathrm{N}$ analyses were carried out in a PerkinElmer $2400 \mathrm{CHNS} / \mathrm{O}$ analyzer.

$\left[\mathrm{Rh}\left(\boldsymbol{\mu}-\mathrm{kO}, \mathbf{O}^{\prime}-\left(\mathrm{CH}_{3}\right)_{2} \mathrm{PO}_{2}\right)(\mathrm{cod})\right]_{2}(\mathbf{1}) .[\mathrm{Rh}(\mu-\mathrm{MeO})(\mathrm{cod})]_{2}(311 \mathrm{mg}$, $0.64 \mathrm{mmol}$ ) was added over a solution of dimethylphosphinic acid $(120 \mathrm{mg}, 1.28 \mathrm{mmol})$ in dichloromethane $(10 \mathrm{~mL})$. The solution was stirred for $18 \mathrm{~h}$ at room temperature. The solvent was then evaporated under reduced pressure and the product obtained as a bright yellow solid $(325 \mathrm{mg}, 0.53 \mathrm{mmol}$, yield = 83\%). ${ }^{1} \mathrm{H}$ NMR (300 MHz, $\mathrm{CDCl}_{3}$ ): $\delta 4.01$ (bs, $8 \mathrm{H}, \mathrm{CH}_{\mathrm{COD}}$ ), 2.80 $2.32\left(\mathrm{~m}, 8 \mathrm{H}, \mathrm{CH}_{2} \mathrm{COD}\right), 1.83-1.54\left(\mathrm{~m}, 8 \mathrm{H}, \mathrm{CH}_{2} \mathrm{COD}\right), 1.27\left(\mathrm{~d},{ }^{2} \mathrm{~J}_{\mathrm{H}-\mathrm{P}}=\right.$ 
12.7, $12 \mathrm{H}, \mathrm{CH}_{3}$ ). ${ }^{1} \mathrm{H}$ NMR (300 MHz, $\mathrm{CD}_{2} \mathrm{Cl}_{2}$ ): $\delta 4.39$ (bs, $8 \mathrm{H}$, $\mathrm{CH}_{\text {COD }}$ ), 2.67-2.39 (m, 8H, $\mathrm{CH}_{2}$ COD), 1.78-1.57 ( $\left.\mathrm{m}, 8 \mathrm{H}, \mathrm{CH}_{2} \mathrm{COD}\right)$, $1.16\left(\mathrm{~d},{ }^{2} \mathrm{~J}_{\mathrm{H}-\mathrm{P}}=13.6,12 \mathrm{H}, \mathrm{CH}_{3}\right) .{ }^{13} \mathrm{C} \mathrm{NMR}\left(75 \mathrm{MHz}, \mathrm{CD}_{2} \mathrm{Cl}_{2}\right): \delta 75.3$ $\left(\mathrm{d},{ }^{1} \mathrm{~J}_{\mathrm{Rh}-\mathrm{P}}=14.9, \mathrm{CH}_{\mathrm{COD}}\right), 31.4\left(\mathrm{~s}, \mathrm{CH}_{2} \mathrm{COD}\right), 19.3\left(\mathrm{~d},{ }^{1} \mathrm{~J}_{\mathrm{C}-\mathrm{P}}=104.9\right.$ $\mathrm{CH}_{3}$ ). ${ }^{31} \mathrm{P}$ NMR (121 MHz, $\mathrm{CD}_{2} \mathrm{Cl}_{2}$ ): $\delta 50.8$ (bs, OPO). Anal. Calcd. for $\mathrm{C}_{20} \mathrm{H}_{36} \mathrm{O}_{4} \mathrm{P}_{2} \mathrm{Rh}_{2}$ (608.02): C, 39.49; $\mathrm{H}$, 5.97. Found: $\mathrm{C}, 39.31 ; \mathrm{H}$, 6.11. HRMS (ESI) $\mathrm{m} / \mathrm{z}$ calcd. for $\mathrm{C}_{20} \mathrm{H}_{36} \mathrm{O}_{4} \mathrm{P}_{2} \mathrm{Rh}_{2}(\mathrm{M}+\mathrm{H})$ 609.0272, found 609.0303.

$\left[\mathrm{Rh}\left(\mu-\mathrm{kO}, \mathrm{O}^{\prime}-\left(\mathrm{CH}_{3}\right)_{2} \mathrm{PO}_{2}\right)(\mathrm{CO})_{2}\right]_{2} \quad$ (2). A stream to carbon monoxide was bubbled through a dichloromethane solution of 1. After 30 minutes the reaction was completed and characterized in situ. ${ }^{1} \mathrm{H}$ NMR $\left(300 \mathrm{MHz}, \mathrm{CD}_{2} \mathrm{Cl}_{2}\right): \delta 1.40$ (d, ${ }^{2} \mathrm{~J}_{\mathrm{H}-\mathrm{P}}$ $\left.=13.9,12 \mathrm{H}, \mathrm{CH}_{3}\right) \cdot{ }^{13} \mathrm{C} \mathrm{NMR}\left(75 \mathrm{MHz}, \mathrm{CD}_{2} \mathrm{Cl}_{2}\right): \delta 182.4\left(\mathrm{~d},{ }^{1} \mathrm{~J}_{\mathrm{C}-\mathrm{Rh}}=\right.$ 40.5, CO), $17.5\left(\mathrm{~d},{ }^{1} \mathrm{~J}_{\mathrm{C}-\mathrm{P}}=98.1, \mathrm{CH}_{3}\right) .{ }^{31} \mathrm{P}$ NMR $\left(121 \mathrm{MHz}, \mathrm{CD}_{2} \mathrm{Cl}_{2}\right)$ : $\delta 59.3$ (bs, OPO).

[Rh(KO- $\left.\left.\left(\mathrm{CH}_{3}\right)_{2} \mathrm{PO}_{2}\right)(\mathrm{CO})_{2} \mathrm{IPr}\right]$ (4). A solution of two equivalents of 1,3-bis(2,6-diisopropylphenyl)-imidazolium (IPr), (64 mg, 0.16 $\mathrm{mmol}$ ) in tetrahydrofuran $(5 \mathrm{ml})$ was added to a solution of the $1(50 \mathrm{mg}, 0.08 \mathrm{mmol})$ in tetrahydrofuran $(5 \mathrm{~mL})$. After stirring the mixture for one hour at room temperature, a stream to carbon monoxide bubbled through the resulting solution at $78 \circ \mathrm{C}$. The reaction was stirred under a $\mathrm{CO}$ atmosphere for $4 \mathrm{~h}$ while the temperature of the bath was allowed to reach room temperature. Then, the solvent was evaporated and the solid was washed with hexane $(3 \times 10 \mathrm{~mL})$. The product was obtained as a white solid $(30 \mathrm{mg}, 0.05 \mathrm{mmol}$, yield $=63 \%) .{ }^{1} \mathrm{H}$ NMR $(300$ $\left.\mathrm{MHz}, \mathrm{CD}_{2} \mathrm{Cl}_{2}\right): \delta 7.52\left(\mathrm{t},{ }^{3} \mathrm{~J}_{\mathrm{H}-\mathrm{H}}=7.8,2 \mathrm{H}, \mathrm{CH}_{\mathrm{Ar}}\right), 7.34\left(\mathrm{~d},{ }^{3} \mathrm{~J}_{\mathrm{H}-\mathrm{H}}=8.1\right.$, $\left.4 \mathrm{H}, \mathrm{CH}_{\mathrm{Ar}}\right), 7.24\left(\mathrm{~s}, 2 \mathrm{H}, \mathrm{CH}_{\text {imidazole }}\right), 2.85$ (sept, ${ }^{3} \mathrm{~J}_{\mathrm{H}-\mathrm{H}}=6.8,4 \mathrm{H}$, $\left.\mathrm{CH}_{\text {ipr }}\right), 1.37\left(\mathrm{~d},{ }^{3} \mathrm{~J}_{\mathrm{H}-\mathrm{H}}=6.7,12 \mathrm{H}, \mathrm{CH}_{3} \mathrm{IPr}\right), 1.13\left(\mathrm{~d},{ }^{3} \mathrm{~J}_{\mathrm{H}-\mathrm{H}}=6.8,12 \mathrm{H}\right.$, $\left.\mathrm{CH}_{3 \text { Pr }}\right), 0.8\left(\mathrm{~d},{ }^{2} \mathrm{~J}_{\mathrm{H}-\mathrm{P}}=13.5,6 \mathrm{H}, \mathrm{PCH}_{3}\right){ }^{13} \mathrm{C} \mathrm{NMR}\left(75 \mathrm{MHz}, \mathrm{CD}_{2} \mathrm{Cl}_{2}\right.$ ): $\delta 185.3\left(\mathrm{~d},{ }^{1} \mathrm{~J}_{\mathrm{C}-\mathrm{Rh}}=69.2, \mathrm{CO}\right), 184.3\left(\mathrm{~d},{ }^{1} \mathrm{~J}_{\mathrm{C}-\mathrm{Rh}}=62.1, \mathrm{CO}\right), 146.45$ (s, $\left.\mathrm{C}_{\text {Ar-orto }}\right), 135.5$ (s, $\left.\mathrm{C}_{\text {Ar-ipso }}\right), 130.8$ (s, $\left.\mathrm{CH}_{\text {Ar-para }}\right), 125.5$ (s, $\left.\mathrm{CH}_{\text {imi }}\right)$, 124.7(s, $\left.\mathrm{CH}_{\text {Ar-meta }}\right), 29.2\left(\mathrm{~s}, \mathrm{CH}_{\mathrm{IPr}}\right), 26.3\left(\mathrm{~s}, \mathrm{CH}_{3 \mathrm{IPr}}\right), 23.2\left(\mathrm{~s}, \mathrm{CH}_{3 \mathrm{Pr}}\right)$, $18.6\left(d,{ }^{1} \mathrm{~J}_{\mathrm{C}-\mathrm{P}}=94.4, \mathrm{PCH}_{3}\right) .{ }^{31} \mathrm{P} \mathrm{NMR}\left(121 \mathrm{MHz} \mathrm{CD}_{2} \mathrm{Cl}_{2}\right): \delta 43.7(\mathrm{~s}$, OPO). IR: $v=1984,1935 \mathrm{~cm}^{-1}$. Anal. Calcd. for $\mathrm{C}_{31} \mathrm{H}_{42} \mathrm{~N}_{2} \mathrm{O}_{4} \mathrm{PRh}$ (640.19): C, 58.13; H, 6.61; N, 4.37. Found: C, 58.45; H, 6.93; N, 4.22. HRMS (ESI) $\mathrm{m} / \mathrm{z}$ calcd. for $\mathrm{C}_{30} \mathrm{H}_{39} \mathrm{~N}_{3} \mathrm{ORh}(\mathrm{M}-\mathrm{CO}-$ $\left.\mathrm{OPO}\left(\mathrm{CH}_{3}\right)_{2}+\mathrm{H}_{3} \mathrm{CN}\right) 560.2133$ found, 560.2143. This peak corresponds to this compound.

$\left[\mathrm{Rh}\left(\mu-\mathrm{kO}, \mathrm{O}^{\prime}-\left(\mathrm{CH}_{3}\right)_{2} \mathrm{PO}_{2}\right)(\mathrm{CO})(\mathrm{IPr})\right]_{2} \quad(5 \mathrm{a})$. Trimethylamine $\mathrm{N}$ oxide $(5 \mathrm{mg}, 0.06 \mathrm{mmol}$ ) was added to a solution of $4(40 \mathrm{mg}$, $0.06 \mathrm{mmol}$ ) in tetrahydrofurane. After $18 \mathrm{~h}$ the solvent was evaporated and the solid washed with hexane $(3 \times 10 \mathrm{~mL})$. A pale yellow solid was obtained (yield $=51 \%, 20 \mathrm{mg}, 0.03 \mathrm{mmol}$ ). ${ }^{1} \mathrm{H}$ NMR (300 MHz, $\left.\mathrm{CD}_{2} \mathrm{Cl}_{2}\right)$ : $\delta 7.49\left(\mathrm{~m}, 4 \mathrm{H}, \mathrm{CH}_{\mathrm{Ar}}\right), 7.31\left(\mathrm{~d}, 3 \mathrm{~J}_{\mathrm{H}-\mathrm{H}}=7.8\right.$, $\left.8 \mathrm{H}, \mathrm{CH}_{\mathrm{Ar}}\right), 7.11\left(\mathrm{~s}, 2 \mathrm{H}, \mathrm{CH}_{\text {imidazole }}\right), 2.79$ (sept, ${ }^{3} \mathrm{~J}_{\mathrm{H}-\mathrm{H}}=6.7,4 \mathrm{H}$, $\left.\mathrm{CH}_{\text {ipr }}\right), 1.28\left(\mathrm{~d},{ }^{3} \mathrm{~J}_{\mathrm{H}-\mathrm{H}}=6.9,24 \mathrm{H}, \mathrm{CH}_{3}(\mathrm{Pr}), 1.03\left(\mathrm{~d},{ }^{3} \mathrm{~J}_{\mathrm{H}-\mathrm{H}}=6.9,24 \mathrm{H}\right.\right.$, $\left.\mathrm{CH}_{3}{ }_{\mathrm{Pr}}\right), 0.82\left(\mathrm{~d},{ }^{2} \mathrm{~J}_{\mathrm{H}-\mathrm{P}}=13.2,12 \mathrm{H}, \mathrm{PCH}_{3}\right) .{ }^{13} \mathrm{C} \mathrm{NMR}(75 \mathrm{MHz}$, $\mathrm{CD}_{2} \mathrm{Cl}_{2}$ ): $\delta 189.5\left(\mathrm{~d},{ }^{1} \mathrm{~J}_{\mathrm{C}-\mathrm{Rh}}=77, \mathrm{CO}\right), 147.03\left(\mathrm{~s}, \mathrm{C}_{\mathrm{Ar}-\text { orto }}\right), 137.4$ (s, $\left.\mathrm{C}_{\text {Ar-ipso }}\right), 130.1$ (s, $\left.\mathrm{CH}_{\text {Ar-para }}\right), 125.5\left(\mathrm{~s}, \mathrm{CH}_{\text {imi }}\right), 124.1\left(\mathrm{~s}, \mathrm{CH}_{\text {Ar-meta }}\right)$, $28.8\left(\mathrm{~s}, \mathrm{CH}_{\mathrm{IPr}}\right), 26.4\left(\mathrm{~s}, \mathrm{CH}_{3} \operatorname{Pr}\right), 23.1\left(\mathrm{~s}, \mathrm{CH}_{3} \operatorname{Pr}\right), 20\left(\mathrm{~d},{ }^{1} \mathrm{~J}_{\mathrm{C}-\mathrm{P}}=96.5\right.$, $\mathrm{PCH}_{3}$ ). ${ }^{31} \mathrm{P} \mathrm{NMR}\left(121 \mathrm{MHz}, \mathrm{CD}_{2} \mathrm{Cl}_{2}\right.$ ): $\delta 53.1$ (s, OPO). IR: $\mathrm{v}=1948$ $\mathrm{cm}^{-1}$. Anal. Calcd. for $\mathrm{C}_{60} \mathrm{H}_{84} \mathrm{~N}_{4} \mathrm{O}_{6} \mathrm{P}_{2} \mathrm{Rh}_{2}\left(1224.39+0.5 \mathrm{CH}_{2} \mathrm{Cl}_{2}\right): \mathrm{C}$, 57.33; $\mathrm{H}, 6.76 ; \mathrm{N}, 4.42$. Found: $\mathrm{C}, 57.05 ; \mathrm{H}, 6.73 ; \mathrm{N}, 4.18$. HRMS (ESI) $\mathrm{m} / \mathrm{z}$ calcd. for $\mathrm{C}_{58} \mathrm{H}_{78} \mathrm{~N}_{4} \mathrm{O}_{4} \mathrm{PRh}_{2}\left(\mathrm{M}-\mathrm{OPO}\left(\mathrm{CH}_{3}\right)_{2}\right) 1131.3865$, found, 1131.3798.

$\left[\mathrm{Rh}\left(\boldsymbol{\mu}-\mathrm{KO}, \mathrm{O}^{\prime}-\left(\mathrm{CH}_{3}\right)_{2} \mathrm{PO}_{2}\right)(\mathrm{CO})\left(\mathrm{PPh}_{3}\right)\right]_{2}$ (5b). Triphenylphosphine (86 $\mathrm{mg}, 0.32 \mathrm{mmol}$ ) were added slowly over a solution of 1 (100mg, 0.16 mmol) in dichloromethane $(15 \mathrm{ml})$. After stirring the mixture for $1 \mathrm{~h}$ at room temperature, a stream to carbon monoxide was bubbled through the solution at -78 ㅇ․ The resulting red solution was stirred under a $\mathrm{CO}$ atmosphere for 2 $h$ while the temperature of the bath increasing to room temperature. The solution was filtered through silica and the volume of solvent reduced to $3 \mathrm{~mL}$ under reduced pressure. Addition of hexane $(10 \mathrm{~mL})$ afforded the title product as a yellow solid (74 mg, $0.08 \mathrm{mmol}$, yield $=47 \%) .{ }^{1} \mathrm{H} \mathrm{NMR}(300 \mathrm{MHz}$, $\left.\mathrm{CD}_{2} \mathrm{Cl}_{2}\right): \delta 7.87-7.74\left(\mathrm{~m}, 10 \mathrm{H}, \mathrm{CH}_{\mathrm{Ar}}\right), 7.46-7.26\left(\mathrm{~m}, 2 \mathrm{H}, \mathrm{CH}_{\mathrm{Ar}}\right)$ $0.98\left(\mathrm{~d},{ }^{2} \mathrm{~J}_{\mathrm{H}-\mathrm{P}}=14.24,12 \mathrm{H}, \mathrm{CH}_{3}\right) .{ }^{13} \mathrm{C} \mathrm{NMR}\left(75 \mathrm{MHz}, \mathrm{CD}_{2} \mathrm{Cl}_{2}\right): \delta$ $189.7\left(\mathrm{dd},{ }^{1} \mathrm{~J}_{\mathrm{C}-\mathrm{Rh}}=77.1,{ }^{1} \mathrm{~J}_{\mathrm{C}-\mathrm{P}}=23.3, \mathrm{CO}\right) 135.1\left(\mathrm{~d},{ }^{2} \mathrm{~J}_{\mathrm{C}-\mathrm{P}}=10.9, \mathrm{C}_{\mathrm{Ar}-}\right.$ orto), $134.1\left(\mathrm{~d},{ }^{1} \mathrm{~J}_{\mathrm{C}-\mathrm{P}}=51.6, \mathrm{C}_{\mathrm{Ar}-\mathrm{ipso}}\right), 130\left(\mathrm{~s}, \mathrm{C}_{\mathrm{Ar}-\mathrm{p}}\right), 128.6\left(\mathrm{~d},{ }^{3} \mathrm{~J}_{\mathrm{C}-\mathrm{P}}=\right.$ 10.9, $\left.\mathrm{C}_{\mathrm{Ar}-\mathrm{m}}\right), 18.3\left(\mathrm{~d},{ }^{1} \mathrm{~J}_{\mathrm{C}-\mathrm{P}}=98, \mathrm{CH}_{3}\right) .{ }^{31} \mathrm{P}$ NMR $\left(121 \mathrm{MHz}, \mathrm{CD}_{2} \mathrm{Cl}_{2}\right)$ : $\delta 52.42(\mathrm{~s}, 2 \mathrm{P}, \mathrm{OPO}), 47.9\left(\mathrm{~d},{ }^{1} \mathrm{~J}_{\mathrm{P}-\mathrm{Rh}}=181.5,2 \mathrm{P}, \mathrm{PPh}_{3}\right) . \mathrm{IR}: \mathrm{v}=1960$ $\mathrm{cm}^{-1}$. Anal. Calcd. for $\mathrm{C}_{42} \mathrm{H}_{42} \mathrm{O}_{6} \mathrm{P}_{4} \mathrm{Rh}_{2}\left(972.00-\left(\mathrm{C}_{2} \mathrm{H}_{5}\right)_{2} \mathrm{O}\right): \mathrm{C}$, 52.79; $\mathrm{H}, 5.01$. Found: $\mathrm{C}, 53.08 ; \mathrm{H}, 4.56$. HRMS (ESI) $\mathrm{m} / \mathrm{z}$ calcd. for $\mathrm{C}_{40} \mathrm{H}_{36} \mathrm{O}_{4} \mathrm{P}_{3} \mathrm{Rh}_{2}\left(\mathrm{M}-\mathrm{OPO}\left(\mathrm{CH}_{3}\right)_{2}\right)$ 878.9931, found, 878.9904. $\left[\mathrm{Rh}\left(\boldsymbol{\mu}-\mathrm{kO}, \mathrm{O}^{\prime}-\left(\mathrm{CH}_{3}\right)_{2} \mathrm{PO}_{2}\right)(\mathrm{CO})\left(\mathrm{PPh}_{2}(\mathrm{OMe})\right)_{2} \quad\right.$ (5c). Methyl diphenylphosphinite $(40 \mu \mathrm{l}, 0.2 \mathrm{mmol})$ was added slowly over a solution of 1 (60 mg, $0.1 \mathrm{mmol})$ in dichloromethane $(15 \mathrm{~mL})$. After stirring the mixture for $1 \mathrm{~h}$ at room temperature, a stream to carbon monoxide was bubbled through the solution at $-78 \circ \mathrm{C}$. The resulting solution was stirred under a $\mathrm{CO}$ atmosphere for 2 $\mathrm{h}$ while the temperature of the bath increasing to room temperature. The solution was filtered through silica and the volume of solvent reduced to $2 \mathrm{~mL}$ under reduced pressure. Addition of hexane $(10 \mathrm{~mL})$ afforded the title product as a yellow solid (40 mg, $0.05 \mathrm{mmol}$, yield $=47 \%) .{ }^{1} \mathrm{H} \mathrm{NMR}(300 \mathrm{MHz}$, $\left.\mathrm{CD}_{2} \mathrm{Cl}_{2}\right)$ : $\delta$ 8.00-7.88 (m, 6H, $\left.\mathrm{CH}_{\mathrm{Ar}}\right), 7.44-7.34\left(\mathrm{~m}, 14 \mathrm{H}, \mathrm{CH}_{\mathrm{Ar}}\right) 3.91$ $\left(d,{ }^{2} \mathrm{~J}_{\mathrm{H}-\mathrm{P}}=13.4,6 \mathrm{H}, \mathrm{POCH}_{3}\right), 1.05\left(\mathrm{~d},{ }^{2} \mathrm{~J}_{\mathrm{H}-\mathrm{P}}=13.9,12 \mathrm{H}, \mathrm{PCH}_{3}\right) .{ }^{13} \mathrm{C}$ NMR $\left(75 \mathrm{MHz}, \mathrm{CD}_{2} \mathrm{Cl}_{2}\right): \delta 188.24\left(\mathrm{dd},{ }^{1} \mathrm{~J}_{\mathrm{C}-\mathrm{Rh}}=74.7,{ }^{1} \mathrm{~J}_{\mathrm{C}-\mathrm{P}}=21.1\right.$, CO), $137.9\left(\mathrm{~d},{ }^{1} \mathrm{~J}_{\mathrm{C}-\mathrm{p}}=57.5, \mathrm{C}_{\mathrm{Ar}-\mathrm{ppso}}\right), 132.2\left(\mathrm{~d},{ }^{2} \mathrm{~J}_{\mathrm{C}-\mathrm{p}}=13.1, \mathrm{C}_{\mathrm{Ar}-\mathrm{o}}\right)$, $131.4\left(\mathrm{~s}, \mathrm{C}_{\mathrm{Ar}-\mathrm{p}}\right), 128.5\left(\mathrm{~d},{ }^{3} \mathrm{~J}_{\mathrm{C}-\mathrm{p}}=11, \mathrm{C}_{\mathrm{Ar}-\mathrm{m}}\right), 56.0\left(\mathrm{~s}, \mathrm{OCH}_{3}\right), 18.4(\mathrm{~d}$, $\left.{ }^{1} \mathrm{~J}_{\mathrm{C}-\mathrm{P}}=97.5, \mathrm{PCH}_{3}\right) .{ }^{31} \mathrm{P}$ NMR $\left(121 \mathrm{MHz}, \mathrm{CD}_{2} \mathrm{Cl}_{2}\right): \delta 135.0\left(\mathrm{~d},{ }^{1} \mathrm{~J}_{\mathrm{P}-\mathrm{Rh}}\right.$ $=199.4$, RhP) 52.5 (s, OPO). IR: v = $1962 \mathrm{~cm}^{-1}$. Anal. Calcd. for $\mathrm{C}_{32} \mathrm{H}_{38} \mathrm{O}_{8} \mathrm{P}_{4} \mathrm{Rh}_{2}$ (879.96): $\mathrm{C}, 43.66 ; \mathrm{H}, 4.35$. Found: $\mathrm{C}, 43.45 ; \mathrm{H}$, 4.19. HRMS (ESI) $\mathrm{m} / \mathrm{z}$ calcd. for $\mathrm{C}_{32} \mathrm{H}_{38} \mathrm{NaO}_{8} \mathrm{P}_{4} \mathrm{Rh}_{2}(\mathrm{M}+\mathrm{Na})$ 902.9519; found, 902.9512. HRMS (ESI) $\mathrm{m} / \mathrm{z}$ calcd. for $\mathrm{C}_{30} \mathrm{H}_{32} \mathrm{O}_{6} \mathrm{P}_{3} \mathrm{Rh}_{2}\left(\mathrm{M}-\mathrm{OPO}\left(\mathrm{CH}_{3}\right)_{2}\right)$ 786.9516, found, 786.9513.

$\left[\mathrm{Rh}\left(\mu-\mathrm{kO}, \mathrm{O}^{\prime}-\left(\mathrm{CH}_{3}\right)_{2} \mathrm{PO}_{2}\right)(\mathrm{CO})\left(\mathrm{P}(\mathrm{OPh})_{3}\right)\right]_{2} \quad(5 \mathrm{~d})$. A solution of triphenylphosphite $(54 \mu \mathrm{L}, 0.19 \mathrm{mmol})$ in dichloromethane (5 $\mathrm{mL}$ ) was added to a solution of $1(60 \mathrm{mg}, 0.1 \mathrm{mmol})$ in dichloromethane $(5 \mathrm{~mL})$. After stirring the mixture for one hour at room temperature, a stream to carbon monoxide was added at $-78^{\circ} \mathrm{C}$. The resulting solution was stirred under a $\mathrm{CO}$ atmosphere for $2 \mathrm{~h}$ while the temperature of the bath increasing to room temperature. Evaporation of the solvent under reduced pressure afforded a waxy solid that was washed with hexane $(3 \times 10 \mathrm{~mL})$ to give the product as an orange solid. (50 mg, $0.05 \mathrm{mmol}$, yield= 52\%). ${ }^{1} \mathrm{H} \mathrm{NMR}\left(300 \mathrm{MHz}, \mathrm{CD}_{2} \mathrm{Cl}_{2}\right): \delta$ 7.39-7.32 (m, 25H, CH $\left.\mathrm{Cr}_{\mathrm{Ar}}\right), 7.22-7.17\left(\mathrm{~m}, 5 \mathrm{H}, \mathrm{CH}_{\mathrm{Ar}}\right) 0.87\left(\mathrm{~d},{ }^{3} \mathrm{~J}_{\mathrm{H}-\mathrm{P}}=\right.$ 13.77, $\left.12 \mathrm{H}, \mathrm{CH}_{3}\right) .{ }^{13} \mathrm{C} \mathrm{NMR}\left(75 \mathrm{MHz}, \mathrm{CD}_{2} \mathrm{Cl}_{2}\right): \delta 186.4\left(\mathrm{dd},{ }^{1} \mathrm{~J}_{\mathrm{C}-\mathrm{Rh}}=\right.$ $\left.75.6,{ }^{1} \mathrm{~J}_{\mathrm{C}-\mathrm{P}}=26.8, \mathrm{CO}\right), 152.7-151.1\left(\mathrm{~m}, \mathrm{C}_{\mathrm{Ar}-\mathrm{ipso}}\right), 130.1\left(\mathrm{~s}, \mathrm{C}_{\mathrm{Ar}}\right)$, $125.4\left(\mathrm{~d}, \mathrm{C}_{\mathrm{Ar}-\mathrm{p}}\right), 121.6\left(\mathrm{~s}, \mathrm{C}_{\mathrm{Ar}}\right), 18.0\left(\mathrm{~d}, \mathrm{~J}_{\mathrm{C}-\mathrm{p}}=98.6, \mathrm{CH}_{3}\right) .{ }^{31} \mathrm{P} \mathrm{NMR}$ $\left(121 \mathrm{MHz}, \mathrm{CD}_{2} \mathrm{Cl}_{2}\right): \delta 117.6\left(\mathrm{~d},{ }^{1} \mathrm{~J}_{\mathrm{P}-\mathrm{Rh}}=302.3,2 \mathrm{P}, \mathrm{P}(\mathrm{OPh})_{3}\right), 53.9$ (s, 2P, OPO). IR: $v=1987 \mathrm{~cm}^{-1}$. HRMS (ESI) $\mathrm{m} / \mathrm{z}$ calcd. for $\mathrm{C}_{40} \mathrm{H}_{36} \mathrm{O}_{10} \mathrm{P}_{3} \mathrm{Rh}_{2}\left(\mathrm{M}-\mathrm{OPO}\left(\mathrm{CH}_{3}\right)_{2}\right)$ 974.9626, found 974.9634 . 
Anal. Calcd. for $\mathrm{C}_{42} \mathrm{H}_{42} \mathrm{O}_{12} \mathrm{P}_{4} \mathrm{Rh}_{2}$ (1067.97-0.5 $\mathrm{CH}_{2} \mathrm{Cl}_{2}$ ): C, 45.95; $H, 3.90$. Found: $C, 46.15 ; H, 4.05$.

General Procedure for the synthesis of hexyl-2-(pyridin-2yl)thiophene-3-carboxylate. 2,2-Thienylpiridyne $(0.2 \mathrm{mmol}, 32$ $\mathrm{mg}), n$-hexanol ( $1 \mathrm{mmol}, 125 \mu \mathrm{L})$, oxone $(0.6 \mathrm{mmol}, 184 \mathrm{mg}$ ) and the corresponding catalyst ( $2 \mathrm{~mol} \%)$ were placed under a CO

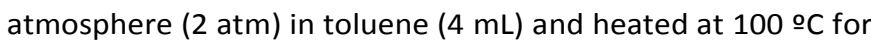
$18 \mathrm{~h}$. Subsequently, the CO was released carefully and the solution was filtered through Celite and the residue washed with dichloromethane. Both fractions were evaporated in vacuo. The resulting oil was dissolved in $1 \mathrm{~mL}$ of dichloromethane and the internal standard (mesitylene, $50 \mu \mathrm{L}$, $0.36 \mathrm{mmol}$ ) was added. Yields were determined by GC analysis of the reaction mixtures with a dilution 1:10 using an Agilent Technologies 6890N. Column: Agilent J\&W HP-Innowax, 0.25 $\mathrm{mm} \times 30 \mathrm{~m} \times 0.25 \mu \mathrm{m}$. The product was purified by flash chromatography on silica gel (hexane: ethyl acetate (9:1), and triethylamine (1\% of the total volume)). ${ }^{1} \mathrm{H} \mathrm{NMR} \mathrm{(300} \mathrm{MHz,}$ $\left.\mathrm{CD}_{2} \mathrm{Cl}_{2}\right): \delta 8.60\left(\mathrm{~d},{ }^{3} \mathrm{~J}_{\mathrm{H}-\mathrm{H}}=4.7,1 \mathrm{H}, \mathrm{NCH}_{\mathrm{py}}\right), 7.83\left(\mathrm{~d},{ }^{3} \mathrm{~J}_{\mathrm{H}-\mathrm{H}}=7.9,1 \mathrm{H}\right.$, $\left.\mathrm{H}_{\mathrm{py}-\mathrm{O}}\right), 7.72\left(\mathrm{td},{ }^{3} J_{\mathrm{H}-\mathrm{H}}=7.6,{ }^{4} J_{\mathrm{H}-\mathrm{H}}=1.4,1 \mathrm{H}, \mathrm{NCHCHCH}_{\mathrm{py}}\right), 7.47(\mathrm{~d}$, $\left.3 J_{\mathrm{H}-\mathrm{H}}=5,1 \mathrm{H}, \mathrm{SCH} H_{\mathrm{Th}}\right), 7.36\left(\mathrm{~d}, 3 \mathrm{~J}_{\mathrm{H}-\mathrm{H}}=5.1,1 \mathrm{H}, \mathrm{SCHCH}_{\mathrm{Th}}\right), 7.30(\mathrm{ddd}$, $\left.{ }^{3} J_{\mathrm{H}-\mathrm{H}}=7.5,4.9,{ }^{4} J_{\mathrm{H}-\mathrm{H}}=1.1 \mathrm{~Hz}, 1 \mathrm{H}, \mathrm{NCHCH}_{\mathrm{py}}\right), 4.20\left(\mathrm{t},{ }^{3} \mathrm{~J}_{\mathrm{H}-\mathrm{H}}=6.6\right.$, $\left.2 \mathrm{H}, \mathrm{COOCH}_{2}\right), 1.68-1.57\left(\mathrm{~m}, 2 \mathrm{H}, \mathrm{CH}_{2}\right), 1.36-1.24\left(\mathrm{~m}, 6 \mathrm{H}, \mathrm{CH}_{2}\right)$, $0.88\left(\mathrm{t},{ }^{3} \mathrm{H}_{\mathrm{H}-\mathrm{H}}=6.6,3 \mathrm{H}, \mathrm{CH}_{3}\right) .{ }^{13} \mathrm{C} \mathrm{NMR}\left(75 \mathrm{MHz}, \mathrm{CD}_{2} \mathrm{Cl}_{2}\right): \delta 163.7$ (s, COO), 151.7 (s, CN), 149.5(s, CS), 149.1 (s, NCH), 135.9 (s, $\mathrm{CH}_{\text {py-m}}$ ), 130.1 (s, $\mathrm{CH}_{\text {thienyl-o }}$ ), 129.3 (s, CCOO), 126.0 (s, $\mathrm{CH}_{\text {thienyl- }}$ m), $124.1\left(\mathrm{~s}, \mathrm{CH}_{\mathrm{ar}-\mathrm{p}}\right), 122.9\left(\mathrm{~s}, \mathrm{CH}_{\mathrm{py}-\mathrm{m}}\right), 65.0\left(\mathrm{~s}, \mathrm{COOCH}_{2}\right), 31.4(\mathrm{~s}$, $\left.\mathrm{CH}_{2}\right), 28.5\left(\mathrm{~s}, \mathrm{CH}_{2}\right), 25.6\left(\mathrm{~s}, \mathrm{CH}_{2}\right), 22.5\left(\mathrm{~s}, \mathrm{CH}_{2}\right), 13.7\left(\mathrm{~s}, \mathrm{CH}_{3}\right)$. HRMS (ESI) $\mathrm{m} / \mathrm{z}$ calcd. for $\mathrm{C}_{16} \mathrm{H}_{19} \mathrm{NO}_{2} \mathrm{~S}(\mathrm{M}+\mathrm{Na}) 312.1029$, found, 312.1027.

X-Ray Data. Crystal data, data collection and refinement parameters for compounds $\mathbf{1}, \mathbf{4}, \mathbf{5 a}$ and $\mathbf{5 c}$ were collected on a Bruker Kappa APEX2 diffractometer equipped with an area detector and graphite monochromated Mo Ka radiation $(0.71073 \AA$ A). Data reduction was carried out with the APEX2 software. ${ }^{[28]}$ All the structures were solved by direct methods and refined by full-matrix least-squares methods based on $F^{2}$ using SHELXL-97 and WinGX programs. ${ }^{[29]}$ Non-hydrogen atoms were refined anisotropically. $\mathrm{H}$ atoms were positioned geometrically and refined with isotropic displacement parameters according to the riding model. Distance and angle calculations were performed using the SHELXL-97 and WinGX programs. ${ }^{[29]}$

Crystal data for compound 1: $\left[\mathrm{C}_{20} \mathrm{H}_{36} \mathrm{O}_{4} \mathrm{P}_{2} \mathrm{Rh}_{2}\right]$, triclinic, $P-1, a=$ 9.5370(15) $\AA, b=9.7552(15) \AA, c=14.656(2) \AA, \alpha=103.267(2)$ 으, $B=95.938(2) \circ, v=117.358(2) \circ, Z=2, M_{r}=608.25, V=1143.8(3)$ $\AA^{3}, D_{\text {calcd }}=1.766 \mathrm{~g} \mathrm{~cm}^{-3}, \lambda($ Mo K $\alpha)=0.71073 \AA, \mathrm{T}=100 \mathrm{~K}, \mu=$ $1.606 \mathrm{~mm}^{-1}, 12054$ reflections collected, 5799 unique $\left(R_{\mathrm{int}}=\right.$ $0.0783), 4355$ observed, $R 1\left(F_{\mathrm{o}}\right)=0.0393[I>2 \sigma(I)], w R 2\left(F_{\mathrm{o}}{ }^{2}\right)=$ 0.0862 (all data), GOF = 1.063. CCDC 1496354 .

Crystal data for compound 4: $\left[\mathrm{C}_{31} \mathrm{H}_{42} \mathrm{~N}_{2} \mathrm{O}_{4} \mathrm{PRh}\right.$ ], orthorhombic, $P 2{ }_{1} 2_{1} 2_{1}, a=10.5240(14) \AA, b=15.865(2) \AA, c=19.108(3) \AA, Z=$

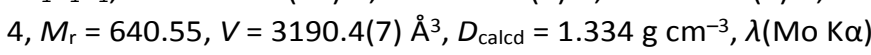
$=0.71073 \AA, \mathrm{T}=100 \mathrm{~K}, \mu=0.621 \mathrm{~mm}^{-1}, 42996$ reflections collected, 8401 unique $\left(R_{\text {int }}=0.0419\right), 7828$ observed, $R 1\left(F_{\mathrm{o}}\right)=$ $0.0256[I>2 \sigma(I)], w R 2\left(F_{\mathrm{o}}{ }^{2}\right)=0.0602$ (all data), GOF $=1.026$. CCDC 1496355.
Crystal data for compound 5a: $\left[\mathrm{C}_{62} \mathrm{H}_{88} \mathrm{Cl}_{4} \mathrm{~N}_{4} \mathrm{O}_{6} \mathrm{P}_{2} \mathrm{Rh}_{2}\right]$, monoclinic, $P 2_{1} / c, a=12.7954(8) \AA, b=17.1516(10) \AA, c=$ 16.0830(10) $\AA, b=107.3960$ (10)ㅇ, $Z=2, M_{\mathrm{r}}=1394.92, V=$ $3368.2(4) \AA^{3}, D_{\text {calcd }}=1.375 \mathrm{~g} \mathrm{~cm}^{-3}, \lambda($ Mo K $\alpha)=0.71073 \AA$, $\mathrm{T}=$ $100 \mathrm{~K}, \mu=0.745 \mathrm{~mm}^{-1}, 82380$ reflections collected, 8426 unique $\left(R_{\text {int }}=0.1104\right), 5954$ observed, $R 1\left(F_{\mathrm{o}}\right)=0.0451[I>2 \sigma(I)]$, $W R 2\left(F_{\mathrm{o}}{ }^{2}\right)=0.0890$ (all data), GOF = 1.024. CCDC 1496356.

Crystal data for compound 5c: $\left[\mathrm{C}_{32} \mathrm{H}_{38} \mathrm{O}_{8} \mathrm{P}_{4} \mathrm{Rh}_{2}\right]$, monoclinic, $C 2 / c, a=19.9476(11) \AA \AA, b=9.3438(5) \AA \AA, c=20.4044(11) \AA$, $b=$ 109.9100(10)으, $Z=4, M_{r}=880.32, V=3575.8(3) \AA^{3}, D_{\text {calcd }}=1.635$

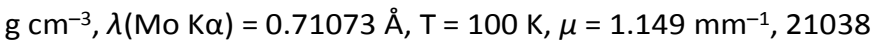
reflections collected, 28.597 unique $\left(R_{\text {int }}=0.0259\right), 25.000$ observed, $R 1\left(F_{\mathrm{o}}\right)=0.0234[I>2 \sigma(l)], w R 2\left(F_{\mathrm{o}}{ }^{2}\right)=0.0595$ (all data), $\mathrm{GOF}=1.024$. CCDC 1496357.

\section{Acknowledgements}

The support of KFUPM (KAST-funded project ART-32-68) and the KFUPM-University of Zaragoza research agreement are highly appreciated This work was further supported by the Spanish Ministry of Economy and Competitiveness (MINECO/FEDER) (CONSOLIDER INGENIO CSD2009-0050) and the Diputación General de Aragón (DGA/FSE-E07).

\section{Notes and references}

1 X. Xu and M. P. Doyle, Acc. Chem. Res. 2014, 47, 1396-1405. 2 a) S. A. Laneman, F. R. Fronczek, G. G. Stanley, J. Am. Chem. Soc. 1988, 110, 5585-5586; b) M. E. Broussard, B. Juma, S. G. Train, W. J. Peng, S. A. Laneman and G. G. Stanley, Science 1993, 260, 1784-1788; c) W. J. Peng, S. G. Train, D. Howell, K. F. R. Fronczek and G. G. Stanley, Chem Commun 1996, 26072612; d) R. C. Matthews, D. K. Howell, W. J. Peng, S. G. Train, W. D. Treleaven and G. G. Stanley, Angew. Chem 1996, 108, 2402-2405; e) R. C. Matthews, D. K. Howell, W. J. Peng, S. G. Train, W. D. Treleaven and G. G. Stanley, Angew. Chem. Int. Ed. Engl. 1996, 35, 2253-2256.

3 M. Iglesias, E. Sola and L. A. Oro, in Top. Organomet. Chem., Vol. 59 (Ed.: P. Kalck), Springer, Cham, 2016, pp. 31-59.

4 For examples see: a) N. Chatani, T. Asaumi, T. Ikeda, S. Yorimitsu, Y. Ishii, F. Kakiuchi and S. Murai,J. Am. Chem. Soc. 2000, 122, 12882-12883; b) L. Rubio-Pérez, M. Iglesias, R. Castarlenas, V. Polo, J. J. Pérez-Torrente and L. A. Oro, ChemCatChem 2014, 6, 3192-3199; c) X. Y. Yu, B. O. Patrick and B. R. James, Organometallics 2006, 25, 4870-4877; d) R. Azpiroz, A. Di Giuseppe, R. Castarlenas, J. J. Pérez-Torrente and L. A. Oro, Chem. Eur. J. 2013, 19, 3812-3816; e) L. RubioPérez, , R. Azpiroz A. Di Giuseppe, V. Polo, R. Castarlenas, J. J. Perez-Torrente and L. A. Oro, Chem. Eur. J. 2013, 19, 1530415314; f) R. Azpiroz, A. Di Giuseppe, R. Castarlenas, J. J. PerezTorrente and L. A. Oro, Chem. Eur. J. 2013, 19, 3812-3816; g) J. Kwak, M. Kim and S. Chang, J. Am. Chem. Soc. 2011, 133, 3780-3783; h) M. Kim, J. Kwak and S. Chang, Angew. Chem. Int. Ed. 2009, 48, 8935-8939; Angew. Chem. 2009, 121, 90979101; i) L. Rubio-Pérez, M. Iglesias, J. Munárriz, V. Polo, J. J. Pérez-Torrente and L. A. Oro, Chem. Eur. J. 2015, 21, 1770117707; j) M. Tobisu, Y. Ano and N. Chatani, Chem. Asian J. 2008, 3, 1585-1591; k) K. Ezbiansky, P. I. Djurovich, M. LaForest, D. J. Sinning, R. Zayes and D. H. Berry, Organometallics 1998, 17, 1455-1457; I) T. Mita, K. Michigami and Y. Sato, Chem. Asian J. 2013, 8, 2970-2973; m) I. D. Kostas, K. A. Vallianatou, P. Kyritsis, J. Zedník and J. Vohlídal, Inorg. Chim. Acta, 2004, 357, 3084-3088; n) A. Nakazato, I. Saeed, T. Katsumata, M. Shiotsuki, T. Masuda, J. Zednik and J. 
Vohlídal, J. Polym. Sci., Part A: Polym. Chem. 2005, 43, 45304536; o) Q. Li, M. Driess and J. F. Hartwig, Angew. Chem., Int. Ed. 2014, 53, 8471-8474.

5 a) J. P. Collman, L. S. Hegedus, J. R. Norton and R. G. Finke, Principles and Applications of Organotransition Metal Chemistry; University Science Books: Mill Valley, CA, 1978; b) J. F. Hartwig in Organotransition metal chemistry - from bonding to catalysis. University Science Books. 2009, 753, 757-578.

6 a) J. F. Roth, J. H. Craddock, A. Hershman and F. E. Paulik, Chem. Tech. 1971, 1, 600-605; b) H. Cheung, R. S. Tanke and Torrence, G. P. Acetic Acid in Ullmann's Encyclopedia of Industrial Chemistry, 2000, Wiley-VCH, Weinheim.

7 For examples of reductive coupling of $\mathrm{C}-\mathrm{H}$ bonds with carbon monoxide and alkenes see: F. J. Fernández-Alvarez, M. Iglesias, L. A. Oro and V. Passarelli, Bond Activation and Catalysis in: Jan Reedijk and Kenneth Poeppelmeier, editors. Comprehensive Inorganic Chemistry II, Vol 8. Oxford: Elsevier; 2013. p. 399-432; and references therein.

8 For examples of alkoxycarbonylation of $\mathrm{C}-\mathrm{H}$ bonds with $\mathrm{CO}$ catalyzed by Rh complexes see: a) Z.-H. Guan, Z.-H. Ren, S. M Spinella, S. Yu, Y.-M. Liang and X. Zhang, J. Am. Chem. Soc. 2009, 131, 729-733; b) R. Lang, J. Wu, L. Shi, C. Xi and F. Li, Chem. Commun., 2011, 47, 12553-12555.

9 For examples of alkoxycarbonylation of $\mathrm{C}-\mathrm{H}$ bonds with $\mathrm{CO}$ catalyzed by Pd complexes see: B. Liu, F. Hu, and B.-F. Shi, ACSCatal. 2015, 5, 1863-1881 (and references therein).

10 J. Otera, Esterification: methods, reactions, and applications; Wiley-VCH: Weinheim, 2010.

11 J. Otera, and J. Nishikido in Esterification: Methods, Reactions, and Applications, $2^{\text {nd }}$ Edition, WILEY-VCH, Weinheim, 2010.

12 F. A. Carey in Organic Chemistry, $4^{\text {th }}$ Edition, McGraw-Hill, New York, 2001, pp. 750-753.

13 B. Liu and B.-F. Shi, Synlett. 2013, 24, 2274-2278.

14 H. Zhang, D. Liu, C.-Y. Chen, C. Liu, and A.-W. Lei, Chem. Eur. J. 2011, 17, 9581-9585.

15 R. W. Wegman, A. G. Abatjoglou and A. M. Harrison, J. Chem. Soc. Chem. Commun. 1987, 1891-1892.

16 M. J. Baker, M. F. Giles, A. G. Orpen, M. J. Taylor and R. J. Watt, J. Chem. Soc. Chem. Commun. 1995, 197-1978.

17 P. Das, D. Konwar, P. Sengupta, D. K. Dutta, Trans. Met. Chem. 2000, 25, 426-429.

18 G. M. Adjabeng, D. A. Gerritsma, H Bhanabhai, C. S. Frampton and A. Capretta, Organometallics 2006, 25, 32-34.

19 a) C. Tejel, M. A. Ciriano, M. Bordonaba, J. A. López, F. J. Lahoz and L. A. Oro, Chem. Eur. J. 2002, 8, 3128-3138; b) C. Tejel, J. M. Villoro, M. A. Ciriano, J. A. López, E. Eguizábal, F. J. Lahoz, V. I. Bakhmutov and L. A. Oro, Organometallics 1996, 15, 2967-2978; c) L. A. Oro, M. A. Ciriano and C. Tejel, Pure Appl. Chem., 1998, 70, 779-788.

20 H. M. D. Bandara, D. Jin, M. A. Mantell, K. D. Field, A. Wang, R. P. Narayanan, N. A. Deskins and M. H. Emmert, Cat. Sci. Techn. 2016, 6, 5304-5310.

21 a) M. Alcarazo Chem. Eur. J. 2014, 20, 7868-7877; b) D. G. Gusev, Organometallics 2009, 28, 763-770.

22 F. E. Hahn and M. C. Jahnke, Angew. Chem. Int. Ed., 2008, 47, 3122-3172.

23 a) L. W. Arndt, B. T. Bancroft, M. Y. Darensbourg, C. P. Janzen, C. M. Kim, J. Reibenspies, K. E. Varner and K. A. Youngdahl, Organometallics 1988, 7, 1302-1309; b) M. Volpe, G. Wu, A Iretskii and P. C. Ford, Inorg. Chem. 2006, 45, 1861-1870; c) J. M. Pearson, A. Haynes, G. E. Morris, G. J. Sunley and P. M. Maitlis, J. Chem. Soc., Chem. Commun., 1995, 1045-1046; d) T. Ghaffar, H. Adams, P. M. Maitlis, G. J. Sunley, M. J. Baker, A Haynes and M. Howard, Chem. Commun. 1998, 1023-1024; e) A. Haynes, P. M. Maitlis, G. E. Morris, G. J. Sunley, H. Adams, P. W. Badger, C. M. Bowers, D. B. Cook, P. I. P. Elliott, T. Ghaffar, H. Green, T. R. Griffin, M. Payne, J. M. Pearson, M. J. Taylor, P. W. Vickers and R. J. Watt, J. Am. Chem. Soc. 2004 126, 2847-2861; f) B. S. Lima Neto, K. H. Ford, A. J. Pardey, R.
J. Rinker and P. C. Ford, Inorg. Chem. 1991, 30, 3837-3842; g) P. C. Ford and A. Rockicki, Adv. Organomet. Chem. 1988, 28, 139-217.

24 M. Albrecht, Chem. Rev. 2010, 110, 576-623.

25 H. Jacobsen, A. Correa, A. Poater, C. Costabile and L. Cavallo, Coord. Chem. Rev. 2009, 253, 687-703.

26 D. W. Allen in Organophosphorus Chemistry, Vol. 44 (Eds. D. W. Allen, D. Loakes and J. C. Tebby), RSC Publishing, Cambridge, 2015, pp. 1-55.

27 a) J. L. Herde, J. C. Lambert, C. V. Senoff, Inorg. Synth. 1982 15, 18-20; b) R. A. Kelly, H. Clavier, S. Giudice, N. M. Scott, E. D. Stevens, J. Bordner, I. Samardjiev, C. D. Hoff, L. Cavallo, S. P. Nolan, Organometallics 2008, 27, 202-210.

28 APEX2 Bruker AXS Inc., Madison, Wisconsin, USA, 2011.

29 a) G. M. Sheldrick, SHELXS-97 and SHELXL-97; University of Göttingen, Germany, 1997; b) L. J. Farrugia, WinGX; University of Glasgow, Great Britain, 1998. 